\title{
Article
}

\section{The Role of Openness in the Effect of ICT on Governance}

\author{
Asongu, Simplice and Nwachukwu, Jacinta Chikaodi \\ Available at http://clok.uclan.ac.uk/25156/ \\ Asongu, Simplice and Nwachukwu, Jacinta Chikaodi ORCID: 0000-0003-2987- \\ 9242 (2018) The Role of Openness in the Effect of ICT on Governance. \\ Information Technology for Development . ISSN 0268-1102
}

It is advisable to refer to the publisher's version if you intend to cite from the work. http://dx.doi.org/10.1080/02681102.2017.1412292

For more information about UCLan's research in this area go to http://www.uclan.ac.uk/researchgroups/ and search for <name of research Group>.

For information about Research generally at UCLan please go to http://www.uclan.ac.uk/research/

All outputs in CLoK are protected by Intellectual Property Rights law, including Copyright law. Copyright, IPR and Moral Rights for the works on this site are retained by the individual authors and/or other copyright owners. Terms and conditions for use of this material are defined in the policies page.

\section{CLoK}

Central Lancashire online Knowledge www.clok.uclan.ac.uk

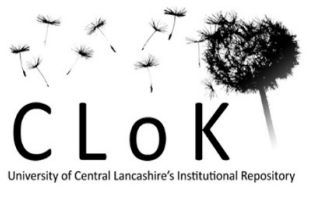




\section{MPRA \\ Munich Personal RePEc Archive}

\section{The Role of Openness in the Effect of ICT on Governance}

Simplice Asongu and Jacinta Nwachukwu

January 2017

Online at https://mpra.ub.uni-muenchen.de/84344/

MPRA Paper No. 84344, posted 4 February 2018 07:26 UTC 


\title{
$\underline{\text { A G D I Working Paper }}$
}

\author{
$\mathrm{WP} / 17 / 050$
}

The Role of Openness in the Effect of ICT on Governance

Forthcoming in Information Technology for Development

\section{Simplice A. Asongu}

African Governance and Development Institute,

P.O Box 8413, Yaoundé, Cameroon.

E-mail: asongusimplice@yahoo.com

\section{Jacinta C. Nwachukwu}

School of Economics, Finance and Accounting,

Faculty of Business and Law,

Coventry University

Priory Street, Coventry, CV1 5FB, UK

Email: jacinta.nwachukwu@coventry.ac.uk 
2017 African Governance and Development Institute

$\mathrm{WP} / 17 / 050$

Research Department

\title{
The Role of Openness in the Effect of ICT on Governance
}

\author{
Simplice A. Asongu \& Jacinta C. Nwachukwu
}

January 2017

\begin{abstract}
The study investigates how openness influences information and communication technology (ICT) penetration for improved government quality in sub-Saharan Africa for the period 2000-2012. Openness is measured in terms of trade and financial globalisation whereas ICT is proxied with mobile phone and internet penetration rates. Ten bundled and unbundled governance indicators are used. The empirical evidence is based on Generalised Method of Moments with forward orthogonal deviations. The main findings are: First, financial openness has an edge over trade openness when combined with ICT to affect both economic and institutional governance. Second, mobile phones have an edge over internet penetration in complementing (i) trade openness for economic governance and (ii) financial openness for institutional governance. Third, net effects on political governance are consistently negative. Taken together, in the short-run, openness-driven ICT policies are more rewarding in terms of economic and institutional governance than political governance. Fourth, catch-up in governance is facilitated by the interaction between openness and ICT. Contributions of these findings to literature are discussed.
\end{abstract}

JEL Classification: F40; O38; O40; O55; P37

Keywords: Openness; ICT; Governance; Africa 


\section{Introduction}

Information technology has been documented to enhance: living standards (Chavula, 2013); economic growth (Levendis \& Lee, 2013; Qureshi, 2013a); welfare externalities (Carmody, 2013; Qureshi, 2013bc); life for all (Kivuneki et al., 2011; Ponelis \& Holmner, 2013ab); banking sector development (Kamel, 2005) and sustainable growth (Byrne, 2011) in developing countries. While information technology has been established to bring about these socio-economic and human development rewards, very little is known about the interaction between information technology and macroeconomic variables for institutional outcomes.

Investigating the role of openness in the effect of information communication technology (ICT) on governance in sub-Saharan Africa (SSA) is motivated by four contemporary strands of the literature, notably, the: (i) growth potential of ICT and recommendations for more scholarly research on the effect of ICT; (ii) ineluctability of openness in $21^{\text {st }}$ century development ${ }^{1}$; (iii) role of institutions in fighting Africa's extreme poverty tragedy and (iv) gaps in the literature on ICT and governance.

First, compared to frontier markets in Asia and the Organisation for Economic Cooperation and Development (OECD) nations that are currently experiencing some degree of stabilisation in the growth of ICT, there is a growth potential in peripheral markets in Africa (Asongu, 2017a; Penard et al., 2012). Penard et al. (2012) reported that the mobile phone and internet penetration rates in Africa were respectively 41 percent and 9.6 percent in 2010. While, the potential for ICT penetration on the continent represents development opportunities, there have been concerns in scholarly circles not to consider ICT as a silver bullet for economic development (Asongu \& De Moor, 2015; Mpogole et al., 2008, p. 71).

Second, openness is essential for the prosperity of nations in the era of globalisation. In essence, there is consensus in the literature that integration into the global economy is indispensable for $21^{\text {st }}$ century development (Oluwatobi et al., 2015; Tchamyou, 2015). According to this strand of literature, Africa is lagging behind in the drive towards knowledge economy (KE) which is crucial for contemporary development (Anyanwu, 2012; Asongu, 2017b). The narrative maintains that the course of global development is being charted by North America and Europe because they are frontier nations that have mastered the dynamics of KE. While the KE pattern of Japan has set the course for the newly industrialised economies of Asia, Malaysia and China, Latin American nations have been responding with policy initiatives that articulate their growing pursuit for KE. This starkly contrasts with KE

\footnotetext{
${ }^{1}$ Openness may be used interchangeably with globalisation throughout the paper.
} 
trends in Africa that have been dropping compared to other regions of the world (see, Anyanwu, 2012).

Third, in the post-2015 sustainable development agenda, institutions are crucial in the fight against SSA's extreme poverty tragedy (Kuada, 2015). The sub-region's poverty tragedy has been recently emphasised by an April 2015 World Bank report on the attainment of Millennium Development Goals (MDGs) extreme poverty target which has revealed that extreme poverty has been decreasing in all regions of the world with the exception of SSA (World Bank, 2015) $)^{2}$. The evidence that 45 percent of countries in the sub-region are off-track from achieving the MDG extreme poverty target greatly contrasts with suggestion that it has been enjoying over two decades of growth resurgence that started in the mid-1990s (see Fosu, 2015 , p. 44). This has motivated a recent stream of literature devoted to understanding Africa's immiserizing growth, notably: (i) Kuada's (2015) proposition of a 'soft economics paradigm' based on human capabilities development and (ii) Fosu's (2015bc) inquiry into whether Africa's growth resurgence is a myth or a reality with assessments of interconnections between institutions and growth in Africa's development. Moreover, the quality of institutions has been established to be strongly linked to inclusive growth, through: strengthening of social change foundations (Efobi, 2015) and improvement of living standards by means of better resource allocation (Fonchingong, 2014; Anyanwu \& Erhijakpor, 2014; Fosu, 2013ab).

Fourth, despite the established roles of institutional quality (Fosu, 2015bc) and ICT (Asongu, 2015) in inclusive development, the literature on development outcomes has not given the link between ICT and institutions the research attention it deserves. Accordingly, as far as we are aware, only four lines of inquiry have assessed the role of ICT on governance in Africa, namely: Porter al. (2016); Gagliardone (2015); Mathias (2012) and Snow (2009). Snow establishes a negative relationship between corruption and ICT while Mathias documents the evolving role of connectivity in boosting accountability on the continent. Gargliardone investigates the relationship between mobile-radio interactions and government quality to establish that such interactions can substantially boost measures taken by the

\footnotetext{
${ }^{2}$ It is important to substantiate how the MDG extreme poverty target, the post-2015 sustainable development agenda and the poverty Sub-Saharan Africa are related. At least six of the seventeen SDGs are concerned with the need to enhance inclusive development, namely: Goal 1(end poverty in all its forms everywhere), Goal 2 (end hunger, achieve food security and improved nutrition and promote sustainable agriculture); Goal 3 (ensure healthy lives and promote well-being for all ages); Goal 4 (ensure inclusive and equitable quality education and promote lifelong learning opportunities for all); Goal 8 (promote sustained, inclusive and sustainable economic growth, full and productive employment and decent work for all ) and Goal 10 (reduce inequality within and among countries). The interested reader can find more information on the SDGs in Michel (2016).
} 
government of Kenya towards prevention and correction. Porter et al. conclude that youth usage of the mobile telephony has great potential of being instrumental for enhancing practical and policy harmony in a sample of selected African countries, namely: Ghana, Malawi and South Africa.

The above literature noticeably leaves space for improvement in four key areas. First, the discussed literature is restricted to selected dimensions of good governance. For example, Snow has exclusively focused on the corruption dimension of good governance. Second, some conclusions are characterised with caveats of correlations, such that causality cannot be inferred for more robust policy implications. For instance, the findings of Snow are statistically fragile because they are interpreted as correlations, not causality. Third, a bulk of the literature is oriented towards country-specific inquiries that have limited policy relevance in terms of scope (e.g. Porter et al., 2016; Snow, 2009). Fourth, the studies have either not directly: (i) involved the use of ICT for good governance (see Gagliardone, 2015) or (ii) focused on good governance as a development outcome (see Porter et al., 2016). Moreover, it is important to model the ICT-governance nexus by integrating openness as a policy tool in order to internalise the ineluctable phenomenon of globalisation. This modelling approach steers clear of techniques in the previous studies that are based on interactions among ICT variables, notably Gargliardone (2015) on radio-mobile interdependencies.

The present inquiry addresses the aforementioned gaps in the literature by investigating the influence of openness in ICT penetration for governance in SSA. More specifically, the research question we seek to answer in this inquiry is: how does openness complement ICT penetration for better governance in SSA?

The rest of the study is organised as follows. Section 2 discusses the theoretical underpinnings and clarifies the concept of governance. The data and methodology are discussed in Section 3. The empirical results, discussion and policy implications are covered in Section 4 while Section 5 concludes.

\section{Clarification of Governance Concepts and Theoretical Highlights}

\subsection{Intuition and theory}

The section discusses the theory behind our topic of research in two main strands, namely: (i) the link between ICT and governance and (ii) the link between openness and governance. We may deal with each in turn.

\subsubsection{Link between ICT and governance}


In accordance with Hellstorm (2008), ICT is a vital tool for enhancing governance because it can improve transparency, accountability and the free-flow of information between several institutions and departments within a government. According to the author, ICT on the one hand eases the participation of citizens in the adoption of decisions that influence their living standards and on the other, enables the diffusion of information between citizens and governments. In summary, better governance is achieved by the means of the ICT enabling the convergence of societies for more participation and information sharing..

In the same vein as the above intuition, Snow (2009, p. 337-339) provided a theoretical account of the link between ICT and improved governance. It was pointed out that the historic dearth of ICT in the African continent provided the elite with a comparative advantage. Such preferential endowments in ICT facilities enabled the ruling classes and their sponsors to evade accountability and transparency, especially in the management of public offices. Under these circumstances, the elite is equally endowed with conducive conditions for rent seeking and corruption in the management of public goods and services. According to Snow (2009), ICT decentralisation should lift the barriers of secrecy that have hitherto enabled the elite to engage in poor governance practices, by improving oversight and accountability with consequent punishment for mismanagement. In summary, the insight underlying this concept is consistent with the logic of Hellstorm (2008) in the perspective that ICT has considerably mitigated information monopoly by the elite which previously facilitated engagement in poor governance and the mismanagement public goods and services (Suarez, 2006; Boulianne, 2009; Diamond, 2010; Grossman et al., 2014).

It is important to balance the above narrative with another aspect of the literature which supports the thesis that ICT could promote political instability and violent actions which are likely to ultimately worsen governance standards (Breuer et al., 2012; Pierskalla \& Hollenbach, 2013; Weidmann \& Shapiro, 2015; Manacorda \& Tesei, 2016).

\subsubsection{Link between openness and governance}

Theoretical underpinnings on the nexus between globalisation and governance has been documented by an interesting stream of literature, inter alia: Klitgaard (1988); Treisman (2000); Bonaglia et al. (2001); Lalountas et al (2011); Amavilah et al. (2014) and Asongu (2014a). These studies are consistent with the positive influence of globalisation on good governance. Lalountas et al and Asongu established the positive relationship between globalisation and corruption-control in developing and African countries respectively. The 
study of Amavilah et al. is based on the positive correlation between globalisation and political stability. Bonaglia et al. built a model in order to show that globalization decreases negative governance signals like corruption. The motivation is consistent with Klitgaard (1998) which maintained that poor governance thrives on scenarios of power monopoly. According to the writers, the incentive to bribery is less apparent in societies where economic activities are undertaken within a framework of perfect competition. In the same vein, poor governance decreases when (i) monopolistic government and economic activities are subject to stringent accountability and (ii) economic rents are not contingent on the discretionary power a few public officials. Hence, Treisman (2000) and Bonaglia et al. (2001) reported political openness to traditions of protestant nature lead to improved governance standards. This position accords with an earlier view by Klitgaard (1988) that less open countries enjoy less political governance.

Despite the hypothesised positive impact of openness on the governance structures of countries, it is important to balance the narrative because the openness-governance relationship is still very much open to different interpretations in the literature. For example, while McMillan (2013) confirmed that institutional reforms in Africa have primarily been driven by openness, there is a version of the literature which maintains that Openness-driven ICT leads to poor governance, because the evolving network of countries and individuals that make-up the complex corruption web are difficult to monitor (see Goredema, 2009 ).

\subsection{Clarification of governance and ICT-governance concepts}

We organise the argument in this section in four main categories: (i) eliciting the concept of ICT governance, (ii) definitions of governance, (iii) debates surrounding the quality of governance indicators and (iv) the motivation for using ten bundled and unbundled governance indicators from the World Bank.

Hellstorm (2008) has clarified ICT-governance by maintaining that the concept should be understood as the employment of ICT to enhance the rewards by all parties involved in electronic (e)-governance. The parties consist of business entities and citizens as well as government units. According to the author, the employment of ICT to improve governance embodies the enhancement of, inter alia: respect of institutions within a country; citizenary participation and delivery of quality public goods and service.

There is an abundant supply of governance definitions in the literature. For the purpose of brevity, we follow Asongu (2016) in providing four definitions from recent 
literature. First, Dixit (2009) has defined economic governance as the '...structure and functioning of the legal and social institutions that support economic activity and economic transactions by protecting property rights, enforcing contracts, and taking collective action to provide physical and organizational infrastructure ${ }^{3}$ (p.5). Second, consistent with Fukuyama (2013), the notion of governance can be improved with the mastery of some main approaches to 'state quality', namely: output measures, political indicators and capacity measures which consist of resource levels and professionalism. Third, with respect to Tusalem (2015), the phenomenon of governance entails: corruption, bureaucratic effectiveness, regulation quality and the rule of law. Fourth, Kaufmann et al. (2010) provide six governance measurements that are classified in three categories, namely: (i) 'political governance' which is the election and replacement of political leaders (proxied with political stability/no violence and voice and accountability); (ii) 'economic governance', which is defined as the formulation and implementation of policies that deliver public commodities (measured with government effectiveness and regulation quality) and (iii) 'institutional governance' which is the respect of the State and citizens of institutions that govern interactions between them (measured with corruption-control and the rule of law).

Concerns about the quality of governance indicators from Kaufmann et al. have been raised in the literature. Kaufmann and co-authors have been quick to respond to criticisms with rebuttals and further clarifications. One of the most heated debates to this end has been with Marcus Kurtz and Andrew Schrank. For the purpose of brevity, the interested reader can have more insight into the debates in: measures and mechanisms (Kurtz \& Schrank, 2007a); a reply (Kaufmann et al., 2007a); a defense (Kurtz \& Schrank, 2007b) and a rejoinder (Kaufmann et al., 2007b).

In this study, the governance indicators adopted are those of Kaufmann et al. (2010) because they are the most widely employed in the literature (see Gani, 2011; Yerrabit \& Hawkes, 2015; Andrés et al., 2015). For the purpose of robustness, we bundle the six governance measurements into four additional governance composite indicators. The motivation for bundling and unbundling governance indicators is consistent with an evolving stream of governance literature, notably: in the prediction of the Arab Spring with negative governance signals (Asongu \& Nwachukwu, 2016a); the importance of economic governance in innovation (Oluwatobi et al., 2015) and ongoing debates on institutional determinants of investment (Asongu et al., 2016).

\footnotetext{
${ }^{3}$ Emphasis on original.
} 


\section{Data and methodology}

\subsection{Data}

This inquiry assesses 49 countries in SSA with data from World Development Indicators (WDI) and World Governance Indicators (WGI) of the World Bank for the period 2000-2012. Consistent with recent knowledge economy literature (Tchamyou, 2015) and the motivation for growth potentials in ICT on the continent discussed in the introduction (see also Penard et al., 2012), ICT is measured in terms of mobile phone and internet penetration rates. Globalisation is approximated by trade (imports plus exports of commodities) and financial (foreign direct investment inflows) openness. The rationale for the choice of these measurements of globalisation is consistent with perception in the existing literature that trade and financial transactions are intuitively connected with ICT (see Amavilah et al., 2014; Asongu, 2014a). A potential weakness of the adopted indicators of trade and financial openness lies in the fact that they are skewed in favour of macroeconomic dimensions. Hence, other aspects of country-level characteristics such as transparency, political and freedom of speech are neglected. A reason for this disregard is that they are broadly captured in the governance structure variables.

The six governance indicators from Kaufmann et al. (2010) are used as dependent variables. These are bundled in Section 3.2.1 by means of principal component analysis (PCA). We have already justified the choice of these variables in the preceding section. They include: corruption-control, the rule of law, institutional governance, government effectiveness, regulation quality, economic governance, political stability/no violence, 'voice and accountability', political governance and general governance.

Five control variables are adopted in order to control for omission variable bias. After a preliminary assessment, including more than five variables in the conditioning information set results in instrument proliferation, meaning that the number of instruments exceeded the number of cross section units in every specification. The control variables are: the lagged dependent indicator, Gross Domestic Product (GDP) growth, population growth, educational quality and foreign aid.

Economic growth and population growth have recently been employed by Asongu and Nwachukwu (2016a) in predicting the Arab Spring based on catch-up in negative governance signals. First, we expect GDP growth to be positively associated with good governance because high-income countries have comparatively better government standards. Second, 
population growth can also be positively linked to governance because more resources are expected to be devoted to the management and service of a rising population. As a caution to this point, it is important to note that population growth may also dampen the government's ability to effectively control the anticipated positive demographic change. Third, the impact of foreign aid on governance has been subject to intense debate. Whereas Okada and Samreth (2012) have concluded on a positive relationship between foreign aid and institutional quality (e.g. corruption) in developing countries, Asongu and Nwachukwu (2016b) have used all the six governance indicators from Kaufmann et al. (2010) employed in this study to consistently establish a negative effect of foreign aid on the underlying government quality dynamics. Fourth, the choice of 'pupil-teacher ratio' in primary education for educational quality is motivated by the evidence that compared to other educational levels, it is more associated with higher social returns in nations at initial stages of industrialisation (see Petrakis \& Stamatakis, 2002; Asiedu, 2014). The expected effect of education is also debatable. While an element of the literature maintains that education worsens governance (Mocan, 2008; Truex, 2011; Kaffenberger, 2012), a contending strand is of the position that schooling improves governance standards (Lederman et al., 2005; Cheung \& Chan, 2008).

The definition of variables and corresponding sources are provided in Appendix 1. The summary statistics is provided in Appendix 2 whereas Appendix 3 presents the pairwise correlation matrix. In the light of information obtained from the summary statistics, two points are worth emphasising. On the one hand, the average values of the variables are comparable. On the other, based on variations from corresponding standard deviations, we can be confident that reasonable estimated linkages would emerge. The objective of the correlation matrix is to mitigate concerns about multicollinearity. From a preliminary assessment, such concerns are apparent among governance variables for the most part. This does not pose any concern about specification bias because the good governance indicators are employed exclusively as dependent variables. The degree of substitution between ICT variables is also high. We address the concern by employing the ICT regressors in distinct specifications.

\subsection{Methodology}

\subsubsection{Principal Component Analysis (PCA)}

The paper employs the PCA technique to bundle the six governance measurements from Kaufmann et al. (2010) into four composite governance measurements, namely: 
political, economic, institutional and general governances. The same procedure for bundling governance has been recently in employed in Asongu and Nwachukwu (2016a) in recent African governance literature. While like in Factor Analysis, PCA is designed for interval data, the technique can also be employed for ordinal data (such as Likert scales), when the indicators are linearly related to one another. This is precisely the case with governance variables which are highly correlated. The PCA is a statistical technique that is used to reduce a set of highly correlated variables into a smaller set of uncorrelated variables called principal components (PCs). The derived PCs constitute substantial information and variation in the dataset. In this light, the six governance measurements are reduced into one common factor known as general governance. Three more indicators are also derived from the six initial measurements, namely: institutional governance (encompassing corruption-control and the rule of the law); political governance (consisting of voice \& accountability and political stability) and economic governance (entailing regulation quality and government effectiveness). Political governance is the election and replacement of political leaders while Economic governance is the formulation and implementation of policies that deliver public commodities. Institutional governance is the respect of the State and citizens of institutions that govern interactions between them. This procedure for bundling and unbundling governance variables by means of PCA is consistent with recent African governance literature (Asongu, 2016; Asongu \& Nwachukwu, 2016a).

The Jolliffe (2002) and Kaiser (1974) criterion is used to retain common factors. In principle, only common factors with an eigenvalue that is higher than the mean or one are retained as composite indicators. Accordingly, from Table 1, the General governance (G.Gov) composite indicator represents more than 81 percent of variation in the six governance variables and has an eigenvalue of 4.892. In the same vein, institutional governance (Instgov), political governance (Polgov) and economic governance (Ecogov) have total variations (eigenvalues) of 93.0 percent, 83.5 percent and 93.9 percent and (1.861, 1.671 and 1.878) respectively.

It is important to allocate space to discussing concerns that may be linked to estimated parameters that are obtained from previous estimations. According to Asongu and Nwachukwu (2016c), the anxieties are linked to the consistency, efficiency and inferential validity of estimated coefficients. According to Pagan (1984, p. 242), whereas two-step estimators are consistent and efficient, very few valid inferences can be obtained. The caution of the author is in accordance with a recent stream of literature surrounding the subject, 
namely: Westerlund and Urbain (2013a); Ba and Ng (2006); McKenzie and McAleer (1997) and Oxley and McAleer (1993).

\section{"Insert Table 1 here"}

Within the framework of this inquiry, we are employing PC-augmented variables. Building on previous works ${ }^{4}$, Westerlund and Urbain $(2012$; 2013b) have provided some insights into the limitation relating to the inferential quality of PC-derived indicators. The authors built on argument in previous studies in establishing that normal inferences are possible from PC-derived regressors provided that estimated coefficients converge to their true values at the rate $\sqrt{N T}$ (with $\mathrm{T}$ being the number of time series and $\mathrm{N}$ denoting crosssection observations). The authors have further maintained that for the convergence to take place, $\mathrm{N}$ and $\mathrm{T}$ need to be sufficiently large. Unfortunately, the authors (Westerlund and Urbain) have failed to specify how 'large is large'. Looking at the specific context of this study, we are working with all the 49 countries in SSA. Hence, we cannot extend N. Stretching $\mathrm{T}$ further would compromise the validity of specifications because it is likely to result in instrument proliferation. Moreover, recent institutional literature based on PCaugmented regressors has concluded using comparatively lower values of $\mathrm{T}$ and $\mathrm{N}$ that valid inferences are possible from bundled governance indicators. For instance, Asongu and Nwachukwu (2016a) is based on 14 Middle East and North African countries for the period 1996-2006 while Asongu (2016) is based on BRICS (Brazil, Russia, India, China and South Africa) and MINT (Mexico, Indonesia, Nigeria and Turkey) for the period 2001-2011. The authors have made a case for the inferential validity of estimated coefficients. Compared to this inquiry, both studies are based on lower values of $\mathrm{N}$ and $\mathrm{T}$.

\subsubsection{Estimation technique}

The study adopts a Generalised Method of Moments (GMM) estimation strategy. Consistent with Tchamyou and Asongu (2017), there are at least five main motivations for the choice of the estimation strategy. The first-two are standard requirements for the adoption of the approach whereas the last-three consist of advantages linked to adoption of the empirical

\footnotetext{
${ }^{4}$ The works include: Stock and Watson (2002); Bai (2003); Pesaran (2006); Bai (2009) and GreenawayMcGrevy et al. (2012).
} 
approach. First, the estimation technique requires that the dependent variables are stable. As apparent in Appendix 4, the governance indicators are persistent because the correlation between levels and their corresponding lagged values is higher than the rule of thumb threshold of 0.800. Second, the number of countries $(\mathrm{N})$ is required to be higher that the number of years (T). This is the case because the $\mathrm{N}(49)>\mathrm{T}(12)$ condition is fulfilled. Third, the estimation technique accounts for endogeneity by controlling for simultaneity and timeinvariant omitted variables. Fourth, cross-country differences are not eliminated in the estimation approach. While country-fixed effects are eliminated in the GMM approach, crosscountry differences are automatically considered in the estimation because the technique is by definition linked to panel data framework. Fifth, small sample biases in the difference estimator are corrected by the system estimator. It is essentially for this fifth reason that Bond et al. (2001, p. 3-4) have maintained that the system GMM technique (Arellano \& Bover, 1995; Blundell \& Bond, 1998) is better than the difference GMM approach (Arellano and Bond, 1991).

This study instead adopts the Roodman (2009ab) extension of Arellano and Bover (1995) that employs forward orthogonal deviations instead of first differences. This GMM extension has been documented to control for cross-sectional dependence and restrict the proliferation of instruments (Love \& Zicchino, 2006; Baltagi, 2008). A two-step specification procedure is adopted because it controls for heteroscedasticity. It is important to note that the one-step approach is homoscedasticity-consistent.

The following equations in levels (1) and first difference (2) summarize the standard system GMM estimation procedure.

$$
\begin{aligned}
G_{i, t}=\sigma_{0}+ & \sigma_{1} G_{i, t-\tau}+\sigma_{2} I C T_{i, t}+\sigma_{3} O p_{i, t}+\sigma_{4} I C T O p_{i, t}+\sum_{h=1}^{4} \delta_{h} W_{h, i, t-\tau}+\eta_{i}+\xi_{t}+\varepsilon_{i, t} \\
G_{i, t}-G_{i, t-\tau} & \sigma_{1}\left(G_{i, t-\tau}-G_{i, t-2 \tau}\right)+\sigma_{2}\left(I C T_{i, t}-I C T_{i, t-\tau}\right)+\sigma_{3}\left(O p_{i, t}-O p_{i, t-\tau}\right)+\sigma_{3}\left(I C T O p_{i, t}-I C T O p_{i, t-\tau}\right) \\
& +\sum_{h=1}^{4} \delta_{h}\left(W_{h, i, t-\tau}-W_{h, i, t-2 \tau}\right)+\left(\xi_{t}-\xi_{t-\tau}\right)+\varepsilon_{i, t-\tau}
\end{aligned}
$$

where $G_{i, t}$ is a governance indicator (political, economic or institutional governance) of country $i$ at period $t ; \sigma_{0}$ is a constant; $\tau$ represents the autoregressive order; ICT, information and communication technology (the mobile phone and internet); $O p$, openness (trade and foreign direct investment); ICTOp, is the interaction between ICT and openness; 
$W$ is the vector of control variables (GDP growth, population growth, educational quality and foreign aid), $\eta_{i}$ is the country-specific effect, $\xi_{t}$ is the time-specific constant and $\varepsilon_{i, t}$ the error term. Since the estimation strategy involves interactive regressions, we are consistent with Brambor et al. (2006) in including all constituent variables in the specifications.

A principal drawback to the GMM approach is the elimination of country-specific effects which substantially account for the unobserved heterogeneity. Unfortunately, this elimination is necessary to avoid estimation biases. Fortunately, the unobserved heterogeneity is also controlled for in the GMM approach using time-invariant omitted variables. Another drawback is that estimated coefficients are interpreted as short-term effects because the employment of GMM is consistent with data averages for the most part. In this study, we are not using data averages.

\subsubsection{Identification and exclusion restriction}

In line with recent literature (Love \& Zicchino, 2006; Dewan \& Ramaprasad, 2014) all independent variables are treated as suspected endogenous or predetermined variables. Hence, we adopt the gmmstyle for them. Moreover, only years are treated as exogenous and the approach for treating ivstyle (years) is 'iv(years, eq(diff))' because it is not unfeasible for the years to become endogenous in first-difference (see Roodman, 2009b).

The issues about simultaneity are addressed by using lagged regressors as instruments for the forward-differenced indicators. Consequently, fixed effects that are likely to affect investigated relationships are removed with Helmet transformations that are performed in line with Love and Zicchino (2006). Such transformations consist of forward mean-differencing of indicators: as opposed to subtracting past observations from present ones (see Roodman, $2009 \mathrm{~b}$, p. 104), the average of future observations is deducted from the variables. The transformation enables parallel or orthogonal conditions between forward-differenced indicators and lagged values. Regardless of the number of lags, in order to reduce the loss of data, the transformations are computed for all observations with the exception of the last for each country. "And because lagged observations do not enter the formula, they are valid as instruments" (Roodman (2009b, p. 104).

In the light of the above, years which are hypothesised to exhibit strict exogeneity influence the dependent variable exclusively via endogenous explaining variables. The statistical validity of the exclusion restriction is examined with the Difference in Hansen Test (DHT) for instrument exogeneity. Accordingly, the null hypothesis of the test should not be 
rejected for the underlying instruments (or years) to explain the outcome variable exclusively through the endogenous explaining variables. The DHT is therefore employed to investigate whether years exhibit strict exogeneity, by not explaining governance beyond the engaged mechanisms (or endogenous explaining variables). Hence, in the section that follows, the reported results should confirm the validity of the exclusion restriction if the null hypotheses of DHT corresponding to IV (year, eq(diff)) are not rejected.

\section{Empirical results}

\subsection{Presentation of results}

In accordance with recent empirical literature that is based on the GMM approach (Asongu \& De Moor, 2017), four principal post-diagnostic information criteria are employed to examined the validity of estimation models. First, the absence of autocorrelation in the residuals is examined by second order Arellano and Bond autocorrelation test in difference $(\mathrm{AR}(2))$ whose null hypothesis for the absence of autocorrelation should not be rejected. Second, the null hypothesis of the Sargan (Hansen) over-identification restrictions (OIR) test which is not robust (robust) because it is based on homoscedasticity (heteroscedasticity) should be rejected for the validity of instruments. Moreover the Sargan (Hansen) is not weakened (weakened) by instruments. Concerns about instrument proliferation that can substantially compromise the validity of estimated models have been limited by ensuring that the rule of thumb requirement for restricting over-identification is met, notably: for each specification, the number of instruments is less the corresponding number of countries. Furthermore, the validity of the Hansen OIR test is further examined with the Difference in Hansen Test (DHT) for exogeneity of instruments. Fourth, a Fisher test that assesses the joint validity of estimated coefficients is also disclosed.

Tables 2, 3, 4 and 5 present findings related to linkages between 'mobile phones, ICT and respectively 'political governance', 'economic governance', 'institutional governance' and 'general governance'. In the light of the study's motivation, we are more apprehensive about the computation of net effects which are computable when two conditions are fulfilled, notably: the unconditional and conditional effects of ICTs should be significant. The conditional or marginal impact is the interaction between ICT and openness. In Table 3 for instance, the net effect from the interaction between mobile phones and financial openness (or FDI) on government effects is $0.0015([-0.00008 \times 5.332]+0.002)$, where: 5.332 is the mean value of FDI. 
The following findings can be established from Table 2. First, there are no significant net effects from the influence of openness in ICT penetration for political governance. Second, most of the significant control variables have expected signs.

We note the following in Table 3 on linkages between ICT, openness and economic governance. First, financial openness is more influential in the positive relationship between ICT and economic governance (government effectiveness and regulation quality) compared to trade openness. Second, for significant associations with trade openness, compared to internet penetration, the mobile phone is more relevant at improving economic governance when combined with trade openness. Third, the control variables are significant with expected signs.

The following findings can be established for Table 4 on linkages between ICT, openness and institutional governance. First, net effects are more significant in regressions pertaining to financial openness. Second, in the financial openness regressions, interactions with mobile phones are more contributory in stimulating institutional governance, compared to those with the internet. In Table 5, only the interaction between internet penetration and financial openness significantly boost general governance. The control variables in Tables 4-5 display expected signs for the most part.

"Insert Tables 2 to 5 here"

\subsection{Further discussion of results and implications}

\subsubsection{Elucidation of positive net effects}

We clarify the positive net effects from both theoretical and practical perspectives. First, from a theoretical angle, the findings are consistent with the theoretical underpinnings on the relationship between openness and good governance. To be sure Bonaglia et al. (2001) established the negative relationship between globalisation and corruption; Klitgaard (1998) opined that in situations of monopoly, poor governance is expected to prosper and Treisman (2000) reported on the improvement of governance standards in tandem with openness. On the practical front, consistent with Snow (2009), four possible rationales elicit the established positive net effects, notably; openness could interact with ICT to enhance: access, reach, interactions and cost-effectiveness. In summary, the relationship is very likely to be apparent because openness complements ICT in mitigating conditions that boost opportunities for bad governance, notably reduction of monopoly and information asymmetry. 


\subsubsection{Practical contributions/implications}

The practical implications are discussed in four principal strands, namely, the: (i) edge of financial openness compared to trade openness in stimulating good governance on the one hand and the edge of the mobile phone in both 'trade openness'- and 'financial openness'related estimations, on the other and (ii) consistent absence of significant net effects on political governance.

First, we have established from the findings that financial openness or financial globalisation has an edge over trade openness when combined with ICT to affect both economic and institutional governances. Second, mobile phones have an edge over internet penetration in complementing (i) trade openness for economic governance and (ii) financial openness for institutional governance. The consistent edge of mobile phones over internet penetration may be traceable to the narrative of Penard et al. (2012) and Asongu (2017a) on the comparatively high penetration of mobile phones over the internet on the continent. Hence, it is logical that the propensity at which openness dynamics interact with mobile phone penetration is higher than that at which openness interacts with internet penetration to affect governance.

Third, an interesting finding that merits substantial clarification is the consistent insignificant net effects on political governance. While this may be surprising because more opened economies are theoretically expected to enjoy higher levels of political governance, in reality however, this may not be the case. We explain this unexpected finding with two streams of discourse, notably (i) time and level hypotheses of for the benefits of political governance from openness and (ii) differences between the Beijing Model (BM) and Washington Consensus (WC) in contemporary development paradigms.

On the one hand, the insignificant effect of the interaction between openness and ICT on political governance may be expected because sampled countries are at early stages of industrialisation. Hence, time and level of openness are required to achieve the rewards of political governance. It is the case of many developing countries after the adoption of openness policies, namely: Turkey (Sayari, 1977) and India (Wade, 1985); Southeast Asia (Scott, 1972); Latin America from waves of political openness (Weyland, 1998) and postcommunist countries in the 1990s (Varsee, 1997).

On the other, from a more contemporary perspective, the insignificant findings of political governance can be elucidated by the two dominant models of development. It is important to first of all define the WC and BM. According to Asongu (2016) whereas the WC 
can be defined as 'liberalised democracy, private capitalism and priority in political rights' and the BM is defined as 'de-emphasised democracy, state capitalism and priority in economic rights'. According to the description, the WC prioritises political governance whereas the BM places more emphasis on economic governance. Asongu and Ssozi (2016) have reconciled the $\mathrm{BM}$ and the $\mathrm{WC}$ by postulating that whereas political governance should be a priority in the long term, the BM should be a priority in the short run. This is essentially because economic governance delivers economic needs (like food, shelter, health and sanitation) while political governance delivers the right to vote (for the most part). The reconciliation of the $\mathrm{BM}$ and the $\mathrm{WC}$ builds on the idea that economic governance should be prioritised at the early stages of industrialisation because a middle class is needed to sustainably demand political rights in the long-term. Hence political governance should be a long-term priority.

In the light of the above, China has achieved her spectacular economic development by tailoring openness for economic and institutional governance and stifling political governance. In the post-independence era, China and African countries were almost in the same economic turmoil. Unfortunately, while China decided to chart its own development course by prioritising economic and institutional governances, most African countries took to prescriptions of the Washington consensus which places more emphasis on political governance. Today, differences in development between African countries and China are selfevident. From the established findings, in the short-run, openness-driven ICT policies are more rewarding in terms of economic and institutional governance than political governance. The short-run inference is based on the perspective that GMM estimates are interpreted as short-run effects.

\subsubsection{Theoretical contributions/implications}

There are two main theoretical contributions of this paper to the literature, notably, insights into information asymmetry and catch-up in governance. First, as concerns information asymmetry, the net positive effects is an indication that ICT reduces information asymmetry by consolidating oversight by public officials, civil society and households. This inference is consistent with evidence that ICT is positively (negatively) linked to the informal (formal) economic sector of African economies (Asongu, 2013) implying that most of civil society organisations working from informal social and politico-economic sectors can also substantially contribute to improving government quality at the advent of globalisation and 
ICT. In summary, ICT driven by openness policies enables information sharing which mitigates information asymmetry or informational rents that were previously used by the elite for corruption and mismanagement. In other words, the interaction between openness and ICT contributes to minimising 'government cost' and allocating resources more efficiently. This inference accords with the theoretical underpinnings of sharing information for financial allocation efficiency in financial institutions (see Claus \& Grimes, 2003). It follows from the established findings that foundations for information sharing in the banking industry can be extended to government institutions.

Second, we have consistently established that past differences in good governance have a less proportionate effect on future differences in good governance. This is essentially because the absolute value of estimates corresponding to the lagged government variable is between zero and one. Hence, the left-hand-side of a system equation is decreasing over time because sampled nations with lower levels of governance are catching-up their counterparts of higher levels. This economic interpretation is an indication that the catch-up theory can be conceived beyond income-convergence (see Asongu, 2014b). Such theoretical contribution is supported both by the literature on the neoclassical growth models (Swan, 1956; Solow, 1956; Baumol, 1986; Barro, 1991; Barro \& Sala-i-Martin, 1992, 1995; Mankiw et al., 1992; Fung, 2009) and other areas of economic development, notably: inclusive human development (Mayer-Foulkes, 2010); financial markets (Bruno et al., 2012; Narayan et al., 2011); knowledge economy (Asongu, 2017b) and negative government signals in the prediction of chaotic events like the 2011 Arab Spring (Asongu \& Nwachukwu, 2016a).

\section{Conclusion and Future Research Directions}

The purpose of this study has been to investigate how openness influences information and communication technology (ICT) penetration for improved government quality in subSaharan Africa for the period 2000-2012. Openness is measured in terms of trade and financial globalisation whereas the ICT is proxied with mobile phone and internet penetration rates. Ten bundled and unbundled governance indicators are used. The empirical evidence is based on Generalised Method of Moments with forward orthogonal deviations. Five main findings emerge.

First, financial openness or financial globalisation has an edge over trade openness when combined with ICT to affect both economic and institutional governance. Second, mobile phones have an edge over internet penetration in complementing: (i) trade openness 
for economic governance and (ii) financial openness for institutional governance. Third, net effects on political governance are consistently negative. Hence, in the short-run opennessdriven ICT policies are more influential in terms of higher levels of economic and institutional governance than political governance. Fourth, countries with low levels of governance are catching-up their counterparts with higher levels of governance. Fifth, only the interaction between internet penetration and financial openness significantly boosts general governance. Practical and theoretical contributions of the findings to the literature have been discussed.

Future studies devoted to extending the established findings could engage countryspecific studies for more targeted policy implications. Moreover, assessing openness and ICT thresholds at which the established findings are more relevant is also an interesting future research direction. The use of estimation techniques that do not eliminate country-specific effects and consider other governance variables is worthwhile. Such would require governance variables from sources like the International Country Risk Guide that have wider time frames to accommodate Fixed Effects regressions.

Table 1: Principal Component Analysis (PCA) for Composite Governance

\begin{tabular}{|c|c|c|c|c|c|c|c|c|c|}
\hline \multirow{2}{*}{$\begin{array}{c}\text { Principal } \\
\text { Components }\end{array}$} & \multicolumn{6}{|c|}{ Component Matrix(Loadings) } & \multirow[t]{2}{*}{ Proportion } & \multirow{2}{*}{$\begin{array}{l}\text { Cumulative } \\
\text { Proportion }\end{array}$} & \multirow{2}{*}{$\begin{array}{l}\text { Eigen } \\
\text { Value } \\
\end{array}$} \\
\hline & VA & PS & RQ & GE & RL & $\mathrm{CC}$ & & & \\
\hline First PC (G.Gov) & 0.395 & 0.372 & 0.411 & 0.426 & 0.439 & 0.404 & 0.815 & 0.815 & 4.892 \\
\hline Second PC & -0.037 & 0.873 & -0.357 & -0.303 & 0.037 & -0.124 & 0.067 & 0.883 & 0.407 \\
\hline Third PC & 0.747 & -0.035 & 0.157 & -0.131 & -0.086 & -0.626 & 0.052 & 0.935 & 0.314 \\
\hline First PC (Polgov) & 0.707 & 0.707 & --- & --- & --- & --- & 0.835 & 0.835 & 1.671 \\
\hline Second PC & -0.707 & 0.707 & --- & --- & --- & --- & 0.164 & 1.000 & 0.328 \\
\hline First PC (Ecogov) & --- & --- & 0.707 & 0.707 & --- & --- & 0.939 & 0.939 & 1.878 \\
\hline Second PC & --- & --- & -0.707 & 0.707 & --- & --- & 0.060 & 1.000 & 0.121 \\
\hline First PC (Instgov) & --- & --- & --- & --- & 0.707 & 0.707 & 0.930 & 0.930 & 1.861 \\
\hline Second PC & --- & --- & --- & --- & -0.707 & 0.707 & 0.069 & 1.000 & 0.138 \\
\hline
\end{tabular}

P.C: Principal Component. VA: Voice \& Accountability. RL: Rule of Law. R.Q: Regulation Quality. GE: Government Effectiveness. PS: Political Stability. CC: Control of Corruption. G.Gov (General Governance): First PC of VA, PS, RQ, GE, RL \& CC. Polgov (Political Governance): First PC of VA \& PS. Ecogov (Economic Governance): First PC of RQ \& GE. Instgov (Institutional Governance): First PC of RL \& CC. 
Table 2: ICT, Openness and Political governance

\begin{tabular}{|c|c|c|c|c|c|c|c|c|c|c|c|c|}
\hline \multirow[b]{3}{*}{ Constant } & \multicolumn{4}{|c|}{ Political Stability(PolSta) } & \multicolumn{4}{|c|}{ Voice and Accountability(VA) } & \multicolumn{4}{|c|}{ Political Governance (PolGov) } \\
\hline & \multicolumn{2}{|c|}{ Trade Openness } & \multicolumn{2}{|c|}{ Financial Openness } & \multicolumn{2}{|c|}{ Trade Openness } & \multicolumn{2}{|c|}{ Financial Openness } & \multicolumn{2}{|c|}{ Trade Openness } & \multicolumn{2}{|c|}{ Financial Openness } \\
\hline & $\begin{array}{l}0.049 \\
(0.610)\end{array}$ & $\begin{array}{l}0.046 \\
(0.678)\end{array}$ & $\begin{array}{l}-0.075 \\
(0.492)\end{array}$ & $\begin{array}{l}0.174 * \\
(0.062)\end{array}$ & $\begin{array}{l}-0.095^{*} \\
(0.059)\end{array}$ & $\begin{array}{l}-0.011 \\
(0.876)\end{array}$ & $\begin{array}{l}0.029 \\
(0.241)\end{array}$ & $\begin{array}{l}-0.151 * * * * \\
(0.000)\end{array}$ & $\begin{array}{l}0.063 \\
(0.549)\end{array}$ & $\begin{array}{l}0.117 \\
(0.229)\end{array}$ & $\begin{array}{l}0.199 * * \\
(0.011)\end{array}$ & $\begin{array}{l}-0.067 \\
(0.541)\end{array}$ \\
\hline PolSta $(-1)$ & $\begin{array}{l}0.811 * * * \\
(0.000)\end{array}$ & $\begin{array}{l}0.830 * * * \\
(0.000)\end{array}$ & $\begin{array}{l}0.862 * * * \\
(0.000)\end{array}$ & $\begin{array}{l}\mathbf{0 . 8 8 0} * * * \\
(\mathbf{0 . 0 0 0})\end{array}$ & --- & --- & --- & --- & --- & --- & --- & --- \\
\hline VA $(-1)$ & --- & --- & --- & --- & $\begin{array}{l}0.961 * * * \\
(0.000)\end{array}$ & $\begin{array}{l}0.912 * * * \\
(0.000)\end{array}$ & $\begin{array}{l}0.991 * * * \\
(0.000)\end{array}$ & $\begin{array}{l}\mathbf{0 . 9 3 3} * * * \\
(\mathbf{0 . 0 0 0 )}\end{array}$ & --- & --- & --- & --- \\
\hline PolGov (-1) & --- & --- & --- & --- & --- & --- & --- & --- & $\begin{array}{l}0.958 * * * \\
(0.000)\end{array}$ & $\begin{array}{l}0.951 * * * \\
(0.000)\end{array}$ & $\begin{array}{l}0.959 * * * \\
(0.000)\end{array}$ & $\begin{array}{l}0.980 * * * \\
(0.000)\end{array}$ \\
\hline Mobile & $\begin{array}{l}0.002 \\
(0.252)\end{array}$ & --- & $\begin{array}{l}0.001 \\
(0.179)\end{array}$ & --- & $\begin{array}{l}0.0009 \\
(0.271)\end{array}$ & --- & $\begin{array}{l}0.0002 \\
(0.414)\end{array}$ & --- & $\begin{array}{l}0.001 \\
(0.590)\end{array}$ & --- & $\begin{array}{l}-0.0003 \\
(0.719)\end{array}$ & --- \\
\hline Internet & --- & $\begin{array}{l}-0.005 \\
(0.396)\end{array}$ & --- & $\begin{array}{l}-0.0006 \\
(0.789)\end{array}$ & --- & $\begin{array}{l}0.009 * * \\
(0.015)\end{array}$ & --- & $\begin{array}{l}0 . .004 * * * \\
(0.001)\end{array}$ & --- & $\begin{array}{l}-0.005 \\
(0.303)\end{array}$ & --- & $\begin{array}{l}0.002 \\
(0.144)\end{array}$ \\
\hline Trade & $\begin{array}{l}0.0005 \\
(0.282)\end{array}$ & $\begin{array}{l}0.0006 \\
(0.409)\end{array}$ & --- & --- & $\begin{array}{l}-\mathbf{0 . 0 0 0 5} * * \\
(0.043)\end{array}$ & $\begin{array}{l}-0.0004 \\
(0.379)\end{array}$ & --- & --- & $\begin{array}{l}0.0002 \\
(0.657)\end{array}$ & $\begin{array}{l}-0.0002 \\
(0.702)\end{array}$ & --- & --- \\
\hline FDI & --- & --- & $\begin{array}{l}-0.0003 \\
(0.901)\end{array}$ & $\begin{array}{l}-0.0008 \\
(0.488)\end{array}$ & --- & --- & $\begin{array}{l}-0.002 * * * \\
(0.004)\end{array}$ & $\begin{array}{l}-0.0003 \\
(0.634)\end{array}$ & --- & --- & $\begin{array}{l}-0.004 * * \\
(0.020)\end{array}$ & $\begin{array}{l}0.0007 \\
(0.598)\end{array}$ \\
\hline Mobile.Trade & $\begin{array}{l}-0.00001 \\
(0.198)\end{array}$ & --- & --- & --- & $\begin{array}{l}0.000001 \\
(0.736)\end{array}$ & --- & --- & --- & $\begin{array}{l}-0.00001 \\
(0.334)\end{array}$ & --- & --- & --- \\
\hline Mobile.FDI & --- & --- & $\begin{array}{l}-0.00001 \\
(0.859)\end{array}$ & --- & --- & --- & $\begin{array}{l}0.00003 * \\
(0.095)\end{array}$ & --- & --- & --- & $\begin{array}{l}0.00004 \\
(0.378)\end{array}$ & --- \\
\hline Internet.Trade & --- & $\begin{array}{l}0.00006 \\
(0.165)\end{array}$ & --- & --- & --- & $\begin{array}{l}-0.00004 \\
(0.115)\end{array}$ & --- & --- & --- & $\begin{array}{l}0.00006 \\
(0.139)\end{array}$ & --- & --- \\
\hline Internet.FDI & --- & --- & --- & $\begin{array}{l}0.00005 \\
(0.350)\end{array}$ & --- & --- & --- & $\begin{array}{l}-0.00008 \\
(0.134)\end{array}$ & --- & --- & --- & $\begin{array}{l}-\mathbf{- 0 . 0 0 0 1} * * \\
(\mathbf{0 . 0 3 3 )}\end{array}$ \\
\hline GDP growth & $\begin{array}{l}0.007 * * * \\
(0.000)\end{array}$ & $\begin{array}{l}0.006 * * * \\
(0.009)\end{array}$ & $\begin{array}{l}\text { 0.006*** } \\
(\mathbf{0 . 0 0 0 )}\end{array}$ & $\begin{array}{l}0.005 * * * \\
(0.001)\end{array}$ & $\begin{array}{l}0.001 \\
(0.187)\end{array}$ & $\begin{array}{l}0.0008 \\
(0.500)\end{array}$ & $\begin{array}{l}0.001 \\
(0.159)\end{array}$ & $\begin{array}{l}0.001 \\
(0.105)\end{array}$ & $\begin{array}{l}0.005 * * * \\
(0.002)\end{array}$ & $\begin{array}{l}0.003 * \\
(0.065)\end{array}$ & $\begin{array}{l}0.007 * * * \\
(0.001)\end{array}$ & $\begin{array}{l}0.006 * * \\
(0.010)\end{array}$ \\
\hline Popg & $\begin{array}{l}0.032 \\
(0.168)\end{array}$ & $\begin{array}{l}-0.011 \\
(0.556)\end{array}$ & $\begin{array}{l}0.079 * * * \\
(0.000)\end{array}$ & $\begin{array}{l}0.052 * * * \\
(0.003)\end{array}$ & $\begin{array}{l}-0.001 \\
(0.886)\end{array}$ & $\begin{array}{l}-0.032 * * * \\
(0.003)\end{array}$ & $\begin{array}{l}0.022 * \\
(0.090)\end{array}$ & $\begin{array}{l}-0.004 \\
(0.500)\end{array}$ & $\begin{array}{l}-0.007 \\
(0.718)\end{array}$ & $\begin{array}{l}-0.030 * \\
(0.060)\end{array}$ & $\begin{array}{l}0.052 * * * \\
(0.000)\end{array}$ & $\begin{array}{l}0.041 * * * \\
(0.005)\end{array}$ \\
\hline Education & $\begin{array}{l}-0.007 * * * * \\
(0.000)\end{array}$ & $\begin{array}{l}-0.003 * * \\
(0.028)\end{array}$ & $\begin{array}{l}-0.005 * * * \\
(0.000)\end{array}$ & $\begin{array}{l}-0.005 * * * \\
(0.009)\end{array}$ & $\begin{array}{l}0.001 * \\
(0.086)\end{array}$ & $\begin{array}{l}0.002 * * \\
(0.011)\end{array}$ & $\begin{array}{l}-0.0004 \\
(0.634)\end{array}$ & $\begin{array}{l}0.002 * * * \\
(0.007)\end{array}$ & $\begin{array}{l}-0.002 \\
(0.191)\end{array}$ & $\begin{array}{l}0.001 \\
(0.552)\end{array}$ & $\begin{array}{l}-0.004 * * * * \\
(0.001)\end{array}$ & $\begin{array}{l}-0.0007 \\
(0.708)\end{array}$ \\
\hline Foreign Aid & $\begin{array}{l}-0.002 * * * \\
(0.000)\end{array}$ & $\begin{array}{l}-0.001 * * \\
(0.037)\end{array}$ & $\begin{array}{l}-0.002 * * * \\
(0.000)\end{array}$ & $\begin{array}{l}-0.001 * * * \\
(0.000)\end{array}$ & $\begin{array}{l}0.00005 \\
(0.918)\end{array}$ & $\begin{array}{l}0.001 * * \\
(0.024)\end{array}$ & $\begin{array}{l}-0.0005 \\
(0.210)\end{array}$ & $\begin{array}{l}0.0006 \\
(0.213)\end{array}$ & $\begin{array}{l}-0.0002 \\
(0.694)\end{array}$ & $\begin{array}{l}0.0005 \\
(0.372)\end{array}$ & $\begin{array}{l}-0.0005 \\
(0.410)\end{array}$ & $\begin{array}{l}-0.001 \\
(0.155)\end{array}$ \\
\hline Net Effects & na & na & na & na & na & na & na & na & na & na & na & na \\
\hline $\mathrm{AR}(1)$ & $(0.000)$ & $(0.000)$ & $(0.000)$ & $(0.000)$ & $(0.005)$ & $(0.005)$ & $(0.006)$ & $(0.006)$ & $(0.001)$ & $(0.002)$ & $(0.001)$ & $(0.002)$ \\
\hline $\mathrm{AR}(2)$ & $(0.352)$ & $(0.362)$ & $(0.454)$ & $(0.428)$ & $(0.959)$ & $(0.993)$ & $(0.934)$ & $(0.894)$ & $(0.404)$ & $(0.539)$ & $(0.386)$ & $(0.497)$ \\
\hline Sargan OIR & $(0.938)$ & $(0.788)$ & $(0.986)$ & $(0.905)$ & $(0.040)$ & $(0.077)$ & $(0.076)$ & $(0.068)$ & $(0.687)$ & $(0.572)$ & $(0.924)$ & $(0.933)$ \\
\hline Hansen OIR & $(0.600)$ & $(0.461)$ & $(0.521)$ & $(0.740)$ & $(0.153)$ & $(0.163)$ & $(0.435)$ & $(0.429)$ & $(0.517)$ & $(0.411)$ & $(0.702)$ & $(0.934)$ \\
\hline $\begin{array}{l}\text { DHT for } \\
\text { instruments } \\
\text { (a)Instruments } \\
\text { in levels }\end{array}$ & & & & & & & & & & & & \\
\hline $\begin{array}{l}\text { H excluding } \\
\text { group }\end{array}$ & $(0.936)$ & $(0.959)$ & $(0.939)$ & $(0.858)$ & $(0.183)$ & $(0.519)$ & $(0.478)$ & $(0.540)$ & $(0.947)$ & $(0.832)$ & $(0.919)$ & $(0.790)$ \\
\hline $\begin{array}{l}\text { Dif(null, } \\
\text { H=exogenous) } \\
\text { (b) IV (years, } \\
\text { eq(diff)) }\end{array}$ & $(0.298)$ & $(0.173)$ & $(0.229)$ & $(0.515)$ & $(0.233)$ & $(0.102)$ & $(0.390)$ & $(0.348)$ & $(0.221)$ & $(0.201)$ & $(0.419)$ & $(0.875)$ \\
\hline $\begin{array}{l}\text { H excluding } \\
\text { group }\end{array}$ & $(0.944)$ & $(0.638)$ & $(0.825)$ & $(0.541)$ & $(0.564)$ & $(0.146)$ & $(0.406)$ & $(0.200)$ & (0.691) & $(0.825)$ & $(0.658)$ & $(0.833)$ \\
\hline $\begin{array}{l}\text { Dif(null, } \\
\mathrm{H}=\text { exogenous) }\end{array}$ & $(0.112)$ & $(0.239)$ & $(\mathbf{0 . 1 5 5})$ & (0.798) & $(0.040)$ & $(0.351)$ & $(0.450)$ & $(0.822)$ & $(0.256)$ & $(0.089)$ & $(0.569)$ & $(0.858)$ \\
\hline Fisher & $882.26 * * *$ & $1608.1 * * *$ & $958.74 * * *$ & $668.98 * * *$ & $1151.3 * * *$ & $1087.1 * * *$ & $1596.3^{* * *}$ & 1037.44 & $1253.0 * * *$ & $3406.5 * * *$ & $1063.4^{* * *}$ & $1254.1 * * *$ \\
\hline Instruments & 39 & 39 & 39 & 39 & 39 & 39 & 39 & & 39 & 39 & 39 & 39 \\
\hline Countries & 46 & 45 & 46 & 45 & 46 & 45 & 46 & & 46 & 45 & 46 & 45 \\
\hline Observations & 320 & 314 & 322 & 316 & 320 & 314 & 322 & & 320 & 314 & 322 & 316 \\
\hline
\end{tabular}

$*, * *, * * *$ : significance levels of $10 \%, 5 \%$ and $1 \%$ respectively. FDI: Foreign Direct Investment. GDP: Gross Domestic Product. Popg: Population growth. DHT: Difference in Hansen Test for Exogeneity of Instruments' Subsets. Dif: Difference. OIR: Over-identifying Restrictions Test. The significance of bold values is twofold. 1) The significance of estimated coefficients and the Fisher statistics. 2) The failure to reject the null hypotheses of: a) no autocorrelation in the AR(1) and AR(2) tests and; b) the validity of the instruments in the Sargan OIR test. na: not applicable due to the insignificance of marginal effects. 
Table 3: ICT, Openness and Economic Governance

\begin{tabular}{|c|c|c|c|c|c|c|c|c|c|c|c|c|}
\hline \multirow[b]{3}{*}{ Constant } & \multicolumn{4}{|c|}{ Government Effectiveness (GE) } & \multicolumn{4}{|c|}{ Regulation Quality (RQ) } & \multicolumn{4}{|c|}{ Economic Governance (EcoGov) } \\
\hline & \multicolumn{2}{|c|}{ Trade Openness } & \multicolumn{2}{|c|}{ Financial Openness } & \multicolumn{2}{|c|}{ Trade Openness } & \multicolumn{2}{|c|}{ Financial Openness } & \multicolumn{2}{|c|}{ Trade Openness } & \multicolumn{2}{|c|}{ Financial Openness } \\
\hline & $\begin{array}{l}-0.261 * * * \\
(0.000)\end{array}$ & $\begin{array}{l}-0.131 * * \\
(0.042)\end{array}$ & $\begin{array}{l}-0.214 * * * \\
(0.001)\end{array}$ & $\begin{array}{l}-0.016 \\
(0.766)\end{array}$ & $\begin{array}{l}-0.226 * * * \\
(0.003)\end{array}$ & $\begin{array}{l}-0.203 * * \\
(0.018)\end{array}$ & $\begin{array}{l}-0.167 * * * \\
(0.000)\end{array}$ & $\begin{array}{l}0.028 \\
(0.554)\end{array}$ & $\begin{array}{l}-0.368 * * * \\
(0.000)\end{array}$ & $\begin{array}{l}-0.282 * * \\
(0.018)\end{array}$ & $\begin{array}{l}-0.203 * * * \\
(0.003)\end{array}$ & $\begin{array}{l}0.094 \\
(0.283)\end{array}$ \\
\hline GE $(-1)$ & $\begin{array}{l}0.869 * * * \\
(\mathbf{0 . 0 0 0 )}\end{array}$ & $\begin{array}{l}0.867 * * * \\
(0.000)\end{array}$ & $\begin{array}{l}0.876 * * * \\
(0.000)\end{array}$ & $\begin{array}{l}0.849 * * * \\
(0.000)\end{array}$ & --- & --- & --- & --- & --- & --- & --- & --- \\
\hline RQ (-1) & --- & --- & --- & --- & $\begin{array}{l}0.857 * * * \\
(\mathbf{0 . 0 0 0 )}\end{array}$ & $\begin{array}{l}0.868^{* * * *} \\
(\mathbf{0 . 0 0 0 )}\end{array}$ & $\begin{array}{l}0.899 * * * \\
(0.000)\end{array}$ & $\begin{array}{l}0.921 * * * \\
(0.000)\end{array}$ & --- & --- & --- & --- \\
\hline EcoGov $(-1)$ & --- & --- & --- & --- & --- & --- & --- & --- & $\begin{array}{l}0.885 * * * \\
(0.000)\end{array}$ & $\begin{array}{l}0.926 * * * \\
(0.000)\end{array}$ & $\begin{array}{l}0.926 * * * \\
(0.000)\end{array}$ & $\begin{array}{l}0.916 * * * \\
(0.000)\end{array}$ \\
\hline Mobile & $\begin{array}{l}0.002 * * * \\
(0.000)\end{array}$ & --- & $\begin{array}{l}\text { 0.002**** } \\
(\mathbf{0 . 0 0 0 )}\end{array}$ & --- & $\begin{array}{l}0.003 * * * \\
(0.000)\end{array}$ & --- & $\begin{array}{l}0.002 * * * \\
(0.000)\end{array}$ & --- & $\begin{array}{l}0.005 * * * \\
(0.000)\end{array}$ & --- & $\begin{array}{l}0.003 * * * \\
(0.000)\end{array}$ & --- \\
\hline Internet & --- & $\begin{array}{l}0.006 * * * \\
(0.003)\end{array}$ & --- & $\begin{array}{l}0.004 * * * \\
(0.001)\end{array}$ & --- & $\begin{array}{l}0.007 * * \\
(0.046)\end{array}$ & --- & $\begin{array}{l}-0.002 * * \\
(0.015)\end{array}$ & --- & $\begin{array}{l}0.012 * * * \\
(0.003)\end{array}$ & --- & $\begin{array}{l}0.001 \\
(0.611)\end{array}$ \\
\hline Trade & $\begin{array}{l}0.0002 \\
(0.266)\end{array}$ & $\begin{array}{l}-0.0002 \\
(0.380)\end{array}$ & --- & --- & $\begin{array}{l}0.00006 \\
(0.784)\end{array}$ & $\begin{array}{l}0.0004 \\
(0.283)\end{array}$ & --- & --- & $\begin{array}{l}0.0004 \\
(0.339)\end{array}$ & $\begin{array}{l}0.001 \\
(0.154)\end{array}$ & --- & --- \\
\hline FDI & --- & --- & $\begin{array}{l}0.002 * * \\
(0.016)\end{array}$ & $\begin{array}{l}-0.0007 * \\
(0.057)\end{array}$ & --- & --- & $\begin{array}{l}0.003 * * * \\
(0.005)\end{array}$ & $\begin{array}{l}-0.002 * * * \\
(0.000)\end{array}$ & --- & --- & $\begin{array}{l}0.007 * * * \\
(0.000)\end{array}$ & $\begin{array}{l}-0.003 * * * \\
(0.000)\end{array}$ \\
\hline Mobile.Trade & $\begin{array}{l}-0.000006 \\
(0.128)\end{array}$ & --- & --- & --- & $\begin{array}{l}-\mathbf{0 . 0 0 0 0 1} \\
* * * \\
(\mathbf{0 . 0 0 2 )}\end{array}$ & --- & --- & --- & $\begin{array}{l}-0.00001 * \\
(0.059)\end{array}$ & --- & --- & --- \\
\hline Mobile.FDI & --- & --- & $\begin{array}{l}-\mathbf{0 . 0 0 0 0 8} \\
* * * \\
(\mathbf{0 . 0 0 1 )}\end{array}$ & --- & --- & --- & $\begin{array}{l}-0.00007 \\
* * * \\
(0.001)\end{array}$ & --- & --- & --- & $\begin{array}{l}-\mathbf{0 . 0 0 0 1} \\
* * * \\
(\mathbf{0 . 0 0 0 )}\end{array}$ & --- \\
\hline Internet.Trade & --- & $\begin{array}{l}-0.000007 \\
(0.659)\end{array}$ & --- & --- & --- & $\begin{array}{l}-0.00002 \\
(0.303)\end{array}$ & --- & --- & --- & $\begin{array}{l}-0.00002 \\
(0.423)\end{array}$ & --- & --- \\
\hline Internet.FDI & --- & --- & -- & $\begin{array}{l}-\mathbf{0 . 0 0 0 0 8} \\
* * \\
(0.017)\end{array}$ & --- & --- & --- & $\begin{array}{l}0.0006 * * * \\
(0.000)\end{array}$ & --- & --- & --- & $\begin{array}{l}0.0007 * * * \\
(0.000)\end{array}$ \\
\hline GDP growth & $\begin{array}{l}0.002 * * * \\
(0.003)\end{array}$ & $\begin{array}{l}0.002 * * * \\
(0.007)\end{array}$ & $\begin{array}{l}0.002 * * * \\
(0.003)\end{array}$ & $\begin{array}{l}0.002 * * \\
(0.037)\end{array}$ & $\begin{array}{l}0.001 \\
(0.134)\end{array}$ & $\begin{array}{l}0.003 * * * \\
(0.009)\end{array}$ & $\begin{array}{l}0.0007 \\
(0.475)\end{array}$ & $\begin{array}{l}0.0002 \\
(0.824)\end{array}$ & $\begin{array}{l}0.005 * * * \\
(0.002)\end{array}$ & $\begin{array}{l}0.003 \\
(0.219)\end{array}$ & $\begin{array}{l}0.002 \\
(0.108)\end{array}$ & $\begin{array}{l}0.001 \\
(0.436)\end{array}$ \\
\hline Popg & $\begin{array}{l}-0.003 \\
(0.804)\end{array}$ & $\begin{array}{l}-0.036 * * * \\
(0.003)\end{array}$ & $\begin{array}{l}0.011 \\
(0.399)\end{array}$ & $\begin{array}{l}-0.016 * \\
(0.085)\end{array}$ & $\begin{array}{l}0.009 \\
(0.161)\end{array}$ & $\begin{array}{l}-0.010 \\
(0.295)\end{array}$ & $\begin{array}{l}0.014 * \\
(0.053)\end{array}$ & $\begin{array}{l}0.009 \\
(0.174)\end{array}$ & $\begin{array}{l}0.015 \\
(0.386)\end{array}$ & $\begin{array}{l}-0.031 * \\
(0.092)\end{array}$ & $\begin{array}{l}0.042 * * \\
(0.016)\end{array}$ & $\begin{array}{l}0.002 \\
(0.870)\end{array}$ \\
\hline Education & $\begin{array}{l}0.001 * \\
(0.056)\end{array}$ & $\begin{array}{l}\mathbf{0 . 0 0 2} * * * \\
(\mathbf{0 . 0 0 7 )}\end{array}$ & $\begin{array}{l}0.0003 \\
(0.645)\end{array}$ & $\begin{array}{l}-0.0004 \\
(0.609)\end{array}$ & $\begin{array}{l}0.0003 \\
(0.645)\end{array}$ & $\begin{array}{l}0.001 \\
(0.126)\end{array}$ & $\begin{array}{l}0.0008 \\
(0.207)\end{array}$ & $\begin{array}{l}-0.001 * \\
(0.084)\end{array}$ & $\begin{array}{l}0.003 * * \\
(0.024)\end{array}$ & $\begin{array}{l}0.005 * * * \\
(0.001)\end{array}$ & $\begin{array}{l}0.002 * \\
(0.099)\end{array}$ & $\begin{array}{l}-0.001 \\
(0.556)\end{array}$ \\
\hline Foreign Aid & $\begin{array}{l}-0.00008 \\
(0.856)\end{array}$ & $\begin{array}{l}0.001 * * * \\
(0.009)\end{array}$ & $\begin{array}{l}-0.0005 \\
(0.521)\end{array}$ & $\begin{array}{l}-0.0002 \\
(0.733)\end{array}$ & $\begin{array}{l}-\mathbf{0 . 0 0 1} * * \\
(0.023)\end{array}$ & $\begin{array}{l}-0.001 * * * \\
(0.003)\end{array}$ & $\begin{array}{l}-0.001 * * \\
(0.019)\end{array}$ & $\begin{array}{l}-0.001 * * * \\
(0.003)\end{array}$ & $\begin{array}{l}-0.001 * * \\
(0.040)\end{array}$ & $\begin{array}{l}-0.0002 \\
(0.829)\end{array}$ & $\begin{array}{l}-0.002 * * \\
(0.014)\end{array}$ & $\begin{array}{l}-0.0005 \\
(0.497)\end{array}$ \\
\hline Net Effects & na & na & 0.0015 & 0.0035 & 0.0022 & na & 0.0016 & 0.0011 & 0.0042 & na & 0.0024 & na \\
\hline $\operatorname{AR}(1)$ & $(0.002)$ & $(0.002)$ & $(0.002)$ & $(0.003)$ & $(0.007)$ & $(0.011)$ & $(0.007)$ & $(0.007)$ & $(0.000)$ & $(0.000)$ & $(0.000)$ & $(0.000)$ \\
\hline $\mathrm{AR}(2)$ & $(0.209)$ & $(0.196)$ & $(0.275)$ & $(0.260)$ & $(0.149)$ & $(0.308)$ & $(0.106)$ & $(0.213)$ & $(0.119)$ & $(0.097)$ & $(0.122)$ & $(0.156)$ \\
\hline Sargan OIR & $(0.356)$ & $(0.376)$ & $(0.446)$ & $(0.295)$ & $(0.001)$ & $(0.001)$ & $(0.001)$ & $(0.000)$ & $(0.095)$ & $(0.142)$ & $(0.098)$ & $(0.028)$ \\
\hline Hansen OIR & $(0.478)$ & $(0.245)$ & $(0.320)$ & $(0.549)$ & $(0.296)$ & $(0.509)$ & $(0.349)$ & $(0.237)$ & $(0.525)$ & $(0.280)$ & $(0.365)$ & $(0.251)$ \\
\hline $\begin{array}{l}\text { DHT for } \\
\text { instruments } \\
\text { (a)Instruments } \\
\text { in levels }\end{array}$ & & & & & & & & & & & & \\
\hline $\begin{array}{l}\text { H excluding } \\
\text { group }\end{array}$ & $(0.350)$ & $(0.518)$ & $(0.744)$ & $(0.772)$ & $(0.152)$ & $(0.576)$ & $(0.115)$ & $(0.212)$ & $(0.558)$ & $(0.518)$ & $(0.139)$ & $(0.142)$ \\
\hline $\begin{array}{l}\text { Dif(null, } \\
\text { H=exogenous) } \\
\text { (b) IV (years, } \\
\text { eq(diff)) }\end{array}$ & $(0.533)$ & $(\mathbf{0 . 1 7 3})$ & $(0.163)$ & $(0.351)$ & $(0.501)$ & $(0.416)$ & $(0.650)$ & $(0.336)$ & $(0.446)$ & $(0.206)$ & $(0.627)$ & $(0.444)$ \\
\hline $\begin{array}{l}\text { H excluding } \\
\text { group }\end{array}$ & $(0.476)$ & $(0.277)$ & $(0.691)$ & $(0.288)$ & $(0.290)$ & $(0.571)$ & $(0.275)$ & $(0.456)$ & $(0.391)$ & $(0.269)$ & $(0.307)$ & $(\mathbf{0 . 1 3 5})$ \\
\hline $\begin{array}{l}\text { Dif(null, } \\
\mathrm{H}=\text { exogenous) }\end{array}$ & $(0.428)$ & $(0.299)$ & $(0.093)$ & $(0.846)$ & $(0.374)$ & $(0.363)$ & $(0.503)$ & $(\mathbf{0 . 1 3 3})$ & $(0.635)$ & $(0.377)$ & $(0.476)$ & $(0.629)$ \\
\hline Fisher & $1060.5 * * *$ & $9169 * * *$ & $4521.9 * * *$ & $1745.8 * * *$ & $7630.2 * * *$ & $936.90 * * *$ & $6792.1 * * *$ & $589.26 * * *$ & $3545.0 * * *$ & $2987.9 * * *$ & $3742.7 * * *$ & $6867.5 * * *$ \\
\hline Instruments & 39 & 39 & 39 & 39 & 39 & 39 & 39 & 39 & 39 & 39 & 39 & 39 \\
\hline Countries & 46 & 45 & 46 & 45 & 46 & 45 & 46 & 46 & 46 & 45 & 46 & 45 \\
\hline Observations & 320 & 314 & 322 & 316 & 320 & 314 & 322 & 316 & 320 & 314 & 322 & 316 \\
\hline
\end{tabular}

*,**,***: significance levels of $10 \%, 5 \%$ and $1 \%$ respectively. FDI: Foreign Direct Investment. GDP: Gross Domestic Product. Popg: Population growth. DHT: Difference in Hansen Test for Exogeneity of Instruments' Subsets. Dif: Difference. OIR: Over-identifying Restrictions Test. The significance of bold values is twofold. 1) The significance of estimated coefficients and the Fisher statistics. 2) The failure to reject the null hypotheses of: a) no autocorrelation in the $\mathrm{AR}(1)$ and $\mathrm{AR}(2)$ tests and; b) the validity of the instruments in the Sargan OIR test. na: not applicable due to the insignificance of marginal effects. 
Table 4: ICT, Openness and Institutional governance

\begin{tabular}{|c|c|c|c|c|c|c|c|c|c|c|c|c|}
\hline \multirow[b]{3}{*}{ Constant } & \multicolumn{4}{|c|}{ Rule of Law (RL) } & \multicolumn{4}{|c|}{ Corruption-Control (CC) } & \multicolumn{4}{|c|}{ Institutional Governance (InstGov) } \\
\hline & \multicolumn{2}{|c|}{ Trade Openness } & \multicolumn{2}{|c|}{ Financial Openness } & \multicolumn{2}{|c|}{ Trade Openness } & \multicolumn{2}{|c|}{ Financial Openness } & \multicolumn{2}{|c|}{ Trade Openness } & \multicolumn{2}{|c|}{ Financial Openness } \\
\hline & $\begin{array}{l}-0.100 * \\
(0.084)\end{array}$ & $\begin{array}{l}-0.031 \\
(0.603)\end{array}$ & $\begin{array}{l}-0.106 * * * \\
(0.005)\end{array}$ & $\begin{array}{l}0.030 \\
(0.352)\end{array}$ & $\begin{array}{l}-0.178 * * * \\
(0.009)\end{array}$ & $\begin{array}{l}0.103^{*} \\
(0.099)\end{array}$ & $\begin{array}{l}-0.012 \\
(0.797)\end{array}$ & $\begin{array}{l}-0.034 \\
(0.570)\end{array}$ & $\begin{array}{l}-0.148 \\
(0.139)\end{array}$ & $\begin{array}{l}0.169 \\
(0.179)\end{array}$ & $\begin{array}{l}0.139 * \\
(0.072)\end{array}$ & $\begin{array}{l}0.165 \\
(0.166)\end{array}$ \\
\hline RL (-1) & $\begin{array}{l}0.900 * * * \\
(0.000)\end{array}$ & $\begin{array}{l}0.932 * * * \\
(0.000)\end{array}$ & $\begin{array}{l}0.888 * * * \\
(\mathbf{0 . 0 0 0 )}\end{array}$ & $\begin{array}{l}0.965 * * * \\
(0.000)\end{array}$ & --- & --- & --- & --- & --- & --- & --- & --- \\
\hline $\mathrm{CC}(-1)$ & --- & --- & --- & --- & $\begin{array}{l}0.786 * * * \\
(0.000)\end{array}$ & $\begin{array}{l}0.837 * * * \\
(\mathbf{0 . 0 0 0 )}\end{array}$ & $\begin{array}{l}0.760 * * * \\
(0.000)\end{array}$ & $\begin{array}{l}0.799 * * * \\
(0.000)\end{array}$ & --- & --- & --- & --- \\
\hline InstGov $(-1)$ & --- & --- & --- & --- & --- & --- & --- & --- & $\begin{array}{l}0.862 * * * \\
(0.000)\end{array}$ & $\begin{array}{l}0.928 * * * \\
(0.000)\end{array}$ & $\begin{array}{l}0.861 * * * \\
(0.000)\end{array}$ & $\begin{array}{l}0.911 * * * \\
(0.000)\end{array}$ \\
\hline Mobile & $\begin{array}{l}0.0009 \\
(0.147)\end{array}$ & --- & $\begin{array}{l}0.001 * * * \\
(0.000)\end{array}$ & --- & $\begin{array}{l}0.002 * * * \\
(0.000)\end{array}$ & --- & $\begin{array}{l}0.002 * * * \\
(0.000)\end{array}$ & --- & $\begin{array}{l}0.004 * * * \\
(0.000)\end{array}$ & --- & $\begin{array}{l}0.003 * * * \\
(0.001)\end{array}$ & --- \\
\hline Internet & --- & $\begin{array}{l}0.003 \\
(0.101)\end{array}$ & --- & $\begin{array}{l}-0.0001 \\
(0.898)\end{array}$ & --- & $\begin{array}{l}0.010^{* * *} \\
(0.010)\end{array}$ & --- & $\begin{array}{l}0.003 * * \\
(0.033)\end{array}$ & --- & $\begin{array}{l}0.013 * * * \\
(0.003)\end{array}$ & --- & $\begin{array}{l}0.004 \\
(0.175)\end{array}$ \\
\hline Trade & $\begin{array}{l}0.0001 \\
(0.572)\end{array}$ & $\begin{array}{l}-0.0003 \\
(0.174)\end{array}$ & --- & --- & $\begin{array}{l}-0.0001 \\
(0.582)\end{array}$ & $\begin{array}{l}-\mathbf{0 . 0 0 1} * * * \\
(\mathbf{0 . 0 0 2})\end{array}$ & --- & --- & $\begin{array}{l}0.00005 \\
(0.902)\end{array}$ & $\begin{array}{l}-0.001 * \\
(0.054)\end{array}$ & --- & --- \\
\hline FDI & --- & --- & $\begin{array}{l}0.002 * * \\
(0.023)\end{array}$ & $\begin{array}{l}-0.0005 \\
(0.271)\end{array}$ & --- & --- & $\begin{array}{l}-0.0001 \\
(0.920)\end{array}$ & $\begin{array}{l}-0.001 * * \\
(0.023)\end{array}$ & --- & --- & $\begin{array}{l}0.002 \\
(0.397)\end{array}$ & $\begin{array}{l}-0.001 \\
(0.123)\end{array}$ \\
\hline Mobile.Trade & $\begin{array}{l}-0.000003 \\
(0.487)\end{array}$ & --- & --- & --- & $\begin{array}{l}-0.000006 \\
(0.239)\end{array}$ & --- & --- & --- & $\begin{array}{l}- \\
0.000009 * \\
(0.096)\end{array}$ & --- & --- & --- \\
\hline Mobile.FDI & --- & --- & $\begin{array}{l}-0.00006 \\
* * * \\
(0.002)\end{array}$ & --- & --- & --- & $\begin{array}{l}-0.00004 * \\
(0.095)\end{array}$ & --- & --- & --- & $\begin{array}{l}-0.00009 \\
* * \\
(0.048)\end{array}$ & --- \\
\hline Internet.Trade & --- & $\begin{array}{l}-0.00001 \\
(0.264)\end{array}$ & --- & --- & --- & $\begin{array}{l}-0.00005 \\
(0.113)\end{array}$ & --- & --- & --- & $\begin{array}{l}-0.00006^{*} \\
(0.779)\end{array}$ & --- & --- \\
\hline Internet.FDI & --- & --- & --- & $\begin{array}{l}0.00007 * \\
(0.078)\end{array}$ & --- & --- & --- & $\begin{array}{l}-0.00007 \\
(0.125)\end{array}$ & --- & --- & --- & $\begin{array}{l}0.00006 \\
(0.715)\end{array}$ \\
\hline GDP growth & $\begin{array}{l}\text { 0.001** } \\
(0.014)\end{array}$ & $\begin{array}{l}0.001 \\
(0.207)\end{array}$ & $\begin{array}{l}0.001 \\
(0.178)\end{array}$ & $\begin{array}{l}0.0009 \\
(0.223)\end{array}$ & $\begin{array}{l}-0.0004 \\
(0.634)\end{array}$ & $\begin{array}{l}-0.0003 \\
(0.803)\end{array}$ & $\begin{array}{l}-0.002 * * * \\
(0.007)\end{array}$ & $\begin{array}{l}-0.002 * * \\
(0.011)\end{array}$ & $\begin{array}{l}0.001 \\
(0.321)\end{array}$ & $\begin{array}{l}0.001 \\
(0.267)\end{array}$ & $\begin{array}{l}-0.001 \\
(0.378)\end{array}$ & $\begin{array}{l}-0.0006 \\
(0.616)\end{array}$ \\
\hline Popg & $\begin{array}{l}0.010 \\
(0.428)\end{array}$ & $\begin{array}{l}0.011 \\
(0.122)\end{array}$ & $\begin{array}{l}\text { 0.041*** } \\
(\mathbf{0 . 0 0 0 )}\end{array}$ & $\begin{array}{l}0.018 * * * \\
(0.004)\end{array}$ & $\begin{array}{l}-0.036 * * \\
(0.019)\end{array}$ & $\begin{array}{l}-0.049 * * * \\
(0.000)\end{array}$ & $\begin{array}{l}-0.020 \\
(0.187)\end{array}$ & $\begin{array}{l}-0.040 * * * \\
(0.006)\end{array}$ & $\begin{array}{l}-0.033 \\
(0.214)\end{array}$ & $\begin{array}{l}-0.040 * \\
(0.079)\end{array}$ & $\begin{array}{l}-0.011 \\
(0.545)\end{array}$ & $\begin{array}{l}-0.033 \\
(0.281)\end{array}$ \\
\hline Education & $\begin{array}{l}-0.0006 \\
(0.464)\end{array}$ & $\begin{array}{l}-0.001 * * \\
(0.011)\end{array}$ & $\begin{array}{l}-0.002 * * * \\
(0.002)\end{array}$ & $\begin{array}{l}-0.002 * * * \\
(0.000)\end{array}$ & $\begin{array}{l}0.0005 \\
(0.493)\end{array}$ & $\begin{array}{l}-0.0008 \\
(0.473)\end{array}$ & $\begin{array}{l}-0.001 * \\
(0.053)\end{array}$ & $\begin{array}{l}-0.0005 \\
(0.624)\end{array}$ & $\begin{array}{l}0.001 \\
(0.292)\end{array}$ & $\begin{array}{l}-0.0006 \\
(0.779)\end{array}$ & $\begin{array}{l}-0.002 * \\
(0.093)\end{array}$ & $\begin{array}{l}-0.001 \\
(0.417)\end{array}$ \\
\hline Foreign Aid & $\begin{array}{l}-0.0005 \\
(0.268)\end{array}$ & $\begin{array}{l}-0.0006 \\
(0.131)\end{array}$ & $\begin{array}{l}-\mathbf{0 . 0 0 1} * * * \\
(0.008)\end{array}$ & $\begin{array}{l}-0.0005 \\
(0.329)\end{array}$ & $\begin{array}{l}0.0003 \\
(0.402)\end{array}$ & $\begin{array}{l}0.001 * * * \\
(0.009)\end{array}$ & $\begin{array}{l}0.0006 * \\
(0.093)\end{array}$ & $\begin{array}{l}0.001 * * * \\
(0.009)\end{array}$ & $\begin{array}{l}0.000006 \\
(0.993)\end{array}$ & $\begin{array}{l}0.001 \\
(0.121)\end{array}$ & $\begin{array}{l}0.0003 \\
(0.624)\end{array}$ & $\begin{array}{l}0.0008 \\
(0.196)\end{array}$ \\
\hline Net Effects & na & na & 0.0006 & na & na & na & 0.0017 & na & 0.0032 & 0.0083 & 0.0025 & na \\
\hline $\operatorname{AR}(1)$ & $(0.005)$ & $(0.006)$ & $(0.006)$ & $(0.006)$ & $(0.001)$ & $(0.000)$ & $(0.001)$ & $(0.000)$ & $(0.003)$ & $(0.004)$ & $(0.003)$ & $(0.003)$ \\
\hline $\mathrm{AR}(2)$ & $(0.210)$ & $(0.236)$ & $(0.210)$ & $(0.217)$ & $(0.354)$ & $(0.400)$ & $(0.366)$ & $(0.417)$ & $(0.178)$ & $(0.210)$ & $(0.202)$ & $(0.205)$ \\
\hline Sargan OIR & $(0.017)$ & $(0.603)$ & $(0.309)$ & $(0.673)$ & $(0.417)$ & $(0.814)$ & $(\mathbf{0 . 3 3 3})$ & $(0.623)$ & $(0.159)$ & $(0.778)$ & $(0.322)$ & $(0.633)$ \\
\hline Hansen OIR & $(0.429)$ & $(\mathbf{0 . 3 3 3})$ & $(\mathbf{0 . 3 3 3})$ & $(0.292)$ & $(0.421)$ & $(0.778)$ & $(\mathbf{0 . 3 5 0})$ & $(0.624)$ & $(0.672)$ & $(0.759)$ & $(0.292)$ & $(0.347)$ \\
\hline $\begin{array}{l}\text { DHT for } \\
\text { instruments } \\
\text { (a)Instruments } \\
\text { in levels }\end{array}$ & & & & & & & & & & & & \\
\hline $\begin{array}{l}\text { H excluding } \\
\text { group }\end{array}$ & $(0.140)$ & $(0.239)$ & $(0.177)$ & $(0.119)$ & $(0.143)$ & $(0.502)$ & $(0.464)$ & $(0.399)$ & $(0.087)$ & $(\mathbf{0 . 2 3 3})$ & $(0.196)$ & $(0.161)$ \\
\hline $\begin{array}{l}\text { Dif(null, } \\
\text { H=exogenous) } \\
\text { (b) IV (years, } \\
\text { eq(diff)) }\end{array}$ & $(0.712)$ & $(0.445)$ & $(0.520)$ & $(0.555)$ & $(0.697)$ & $(0.794)$ & $(\mathbf{0 . 3 0 3})$ & $(0.675)$ & $(0.978)$ & $(0.932)$ & $(\mathbf{0 . 4 3 5})$ & $(0.565)$ \\
\hline $\begin{array}{l}\text { H excluding } \\
\text { group }\end{array}$ & $(0.555)$ & $(0.200)$ & $(0.551)$ & $(0.349)$ & $(0.525)$ & $(0.876)$ & $(0.450)$ & $(0.452)$ & $(0.567)$ & $(0.650)$ & $(0.572)$ & $(0.444)$ \\
\hline $\begin{array}{l}\text { Dif(null, } \\
\mathrm{H}=\text { exogenous) }\end{array}$ & $(0.274)$ & $(0.634)$ & $(0.170)$ & $(0.289)$ & $(0.291)$ & $(0.386)$ & $(0.268)$ & $(0.716)$ & $(0.638)$ & $(0.689)$ & $(\mathbf{0 . 1 2 3})$ & $(0.270)$ \\
\hline Fisher & $299.39 * * *$ & $5593.8 * * *$ & $857.68 * * *$ & $2501.2 * * *$ & $1134.7 * * *$ & $748.00 * * *$ & $466.82 * * *$ & $691.66^{* * *}$ & $785.00 * * *$ & $2012.2 * * *$ & $959.19 * * *$ & $3008 * * *$ \\
\hline Instruments & 39 & 39 & 39 & 39 & 39 & 39 & 39 & 39 & 39 & 39 & 39 & 39 \\
\hline Countries & 46 & 45 & 46 & 45 & 46 & 45 & 46 & 45 & 46 & 45 & 46 & 45 \\
\hline Observations & 320 & 312 & 322 & 316 & 320 & 314 & 322 & 316 & 320 & 314 & 322 & 316 \\
\hline
\end{tabular}

***,***: significance levels of $10 \%, 5 \%$ and $1 \%$ respectively. FDI: Foreign Direct Investment. GDP: Gross Domestic Product. Popg: Population growth. DHT: Difference in Hansen Test for Exogeneity of Instruments' Subsets. Dif: Difference. OIR: Over-identifying Restrictions Test. The significance of bold values is twofold. 1) The significance of estimated coefficients and the Fisher statistics. 2) The failure to reject the null hypotheses of: a) no autocorrelation in the $\mathrm{AR}(1)$ and $\mathrm{AR}(2)$ tests and; b) the validity of the instruments in the Sargan OIR test. na: not applicable due to the insignificance of marginal effects. 
Table 5: ICT, Openness and General Governance

\begin{tabular}{|c|c|c|c|c|}
\hline \multirow{4}{*}{ Constant } & \multicolumn{4}{|c|}{ General Governance (G.Gov) } \\
\hline & \multicolumn{2}{|c|}{ Trade Openness } & \multicolumn{2}{|c|}{ Financial Openness } \\
\hline & $-0.409 * * *$ & -0.153 & $-0.204 * *$ & -0.024 \\
\hline & $(0.002)$ & $(0.308)$ & $(\mathbf{0 . 0 2 2})$ & $(0.833)$ \\
\hline \multirow[t]{2}{*}{ G.Gov $(-1)$} & $0.966 * * *$ & $0.956 * * *$ & $0.954 * * *$ & $0.943 * * *$ \\
\hline & $(0.000)$ & $(0.000)$ & $(0.000)$ & $(0.000)$ \\
\hline \multirow[t]{2}{*}{ Mobile } & 0.002 & --- & $0.003 * * *$ & --- \\
\hline & $(0.196)$ & & $(0.000)$ & \\
\hline \multirow[t]{2}{*}{ Internet } & --- & $0.012 * *$ & --- & $0.006 * *$ \\
\hline & & $(\mathbf{0 . 0 3 2})$ & & $(0.015)$ \\
\hline \multirow[t]{2}{*}{ Trade } & $0.0009 *$ & -0.0001 & --- & --- \\
\hline & $(0.063)$ & $(0.894)$ & & \\
\hline \multirow[t]{2}{*}{ FDI } & --- & --- & 0.001 & -0.002 \\
\hline & & & $(0.647)$ & $(0.112)$ \\
\hline \multirow[t]{2}{*}{ Mobile.Trade } & 0.0000004 & --- & --- & --- \\
\hline & $(0.973)$ & & & \\
\hline \multirow[t]{2}{*}{ Mobile.FDI } & --- & --- & -0.00006 & --- \\
\hline & & & $(0.304)$ & \\
\hline \multirow[t]{2}{*}{ Internet.Trade } & --- & -0.00001 & --- & --- \\
\hline & & $(0.731)$ & & \\
\hline \multirow[t]{2}{*}{ Internet.FDI } & --- & --- & --- & $0.0002 * *$ \\
\hline & & & & $(0.017)$ \\
\hline \multirow[t]{2}{*}{ GDP growth } & $0.005 * *$ & $0.005 * *$ & 0.003 & 0.003 \\
\hline & $(0.011)$ & $(\mathbf{0 . 0 2 2})$ & $(0.118)$ & $(0.120)$ \\
\hline \multirow[t]{2}{*}{ Popg } & 0.033 & $-0.048 * *$ & $0.065 * * *$ & 0.005 \\
\hline & $(0.248)$ & $(0.010)$ & $(0.007)$ & $(0.737)$ \\
\hline \multirow[t]{2}{*}{ Education } & $0.004 * * *$ & $0.005 * * *$ & 0.001 & 0.0007 \\
\hline & $(0.008)$ & $(0.006)$ & $(0.232)$ & $(0.695)$ \\
\hline \multirow[t]{2}{*}{ Foreign Aid } & -0.001 & 0.001 & -0.001 & -0.0009 \\
\hline & $(0.262)$ & $(0.304)$ & $(0.341)$ & $(0.642)$ \\
\hline Net Effects & na & na & na & 0.0070 \\
\hline $\mathrm{AR}(1)$ & $(0.001)$ & $(0.002)$ & $(0.001)$ & $(0.002)$ \\
\hline $\operatorname{AR}(2)$ & $(0.241)$ & $(0 . .245)$ & $(0.280)$ & $(0.309)$ \\
\hline Sargan OIR & $(0.096)$ & $(0.628)$ & $(0.459)$ & $(0.630)$ \\
\hline Hansen OIR & $(0.210)$ & $(0.200)$ & $(0.394)$ & $(0.151)$ \\
\hline \multirow{2}{*}{\multicolumn{5}{|c|}{$\begin{array}{l}\text { DHT for instruments } \\
\text { (a)Instruments in levels }\end{array}$}} \\
\hline & & & & \\
\hline H excluding group & $(\mathbf{0 . 1 5 3 )}$ & $(0.366)$ & $(0.285)$ & $(\mathbf{0 . 1 3 5})$ \\
\hline Dif(null, $\mathrm{H}=$ exogenous) & $(0.359)$ & $(0.185)$ & $(0.483)$ & $(0.278)$ \\
\hline \multicolumn{5}{|l|}{ (b) IV (years, eq(diff)) } \\
\hline $\mathrm{H}$ excluding group & $(0.531)$ & $(0.154)$ & $(0.363)$ & $(0.100)$ \\
\hline Dif(null, $\mathrm{H}=$ exogenous) & $(0.079)$ & $(0.433)$ & $(0.442)$ & $(0.460)$ \\
\hline Fisher & $3166.34 * * *$ & $9486.95 * * *$ & $3478.63 * * *$ & $8186.55 * * *$ \\
\hline Instruments & 39 & 39 & 39 & 39 \\
\hline Countries & 46 & 45 & 46 & 45 \\
\hline Observations & 320 & 314 & 322 & 316 \\
\hline
\end{tabular}

*,**,***: significance levels of $10 \%, 5 \%$ and $1 \%$ respectively. FDI: Foreign Direct Investment. GDP: Gross Domestic Product. Popg: Population growth. DHT: Difference in Hansen Test for Exogeneity of Instruments' Subsets. Dif: Difference. OIR: Over-identifying Restrictions Test. The significance of bold values is twofold. 1) The significance of estimated coefficients and the Fisher statistics. 2) The failure to reject the null hypotheses of: a) no autocorrelation in the AR(1) and AR(2) tests and; b) the validity of the instruments in the Sargan OIR test. na: not applicable due to the insignificance of marginal effects. 


\section{Appendices}

Appendix 1: Variable Definitions

\begin{tabular}{|c|c|c|c|}
\hline Variables & Signs & Variable Definitions (Measurements) & Sources \\
\hline Political Stability & PolSta & $\begin{array}{l}\text { "Political stability/no violence (estimate): measured as the } \\
\text { perceptions of the likelihood that the government will be } \\
\text { destabilized or overthrown by unconstitutional and violent } \\
\text { means, including domestic violence and terrorism" }\end{array}$ & World Bank (WDI) \\
\hline $\begin{array}{l}\text { Voice \& } \\
\text { Accountability }\end{array}$ & V\&A & $\begin{array}{l}\text { "Voice and accountability (estimate): measures the extent to } \\
\text { which a country's citizens are able to participate in selecting } \\
\text { their government and to enjoy freedom of expression, freedom } \\
\text { of association and a free media". }\end{array}$ & World Bank (WDI) \\
\hline $\begin{array}{l}\text { Political } \\
\text { Governance }\end{array}$ & Polgov & $\begin{array}{l}\text { First Principal Component of Political Stability and Voice \& } \\
\text { Accountability. The process by which those in authority are } \\
\text { selected and replaced. }\end{array}$ & PCA \\
\hline $\begin{array}{l}\text { Government } \\
\text { Effectiveness }\end{array}$ & Gov. E & $\begin{array}{l}\text { "Government effectiveness (estimate): measures the quality of } \\
\text { public services, the quality and degree of independence from } \\
\text { political pressures of the civil service, the quality of policy } \\
\text { formulation and implementation, and the credibility of } \\
\text { governments' commitments to such policies". }\end{array}$ & World Bank (WDI) \\
\hline $\begin{array}{l}\text { Regulation } \\
\text { Quality }\end{array}$ & RQ & $\begin{array}{l}\text { "Regulation quality (estimate): measured as the ability of the } \\
\text { government to formulate and implement sound policies and } \\
\text { regulations that permit and promote private sector } \\
\text { development". }\end{array}$ & World Bank (WDI) \\
\hline $\begin{array}{l}\text { Economic } \\
\text { Governance }\end{array}$ & Ecogov & $\begin{array}{l}\text { "First Principal Component of Government Effectiveness and } \\
\text { Regulation Quality. The capacity of government to formulate } \\
\text { \& implement policies, and to deliver services". }\end{array}$ & PCA \\
\hline Rule of Law & RL & $\begin{array}{l}\text { "Rule of law (estimate): captures perceptions of the extent to } \\
\text { which agents have confidence in and abide by the rules of } \\
\text { society and in particular the quality of contract enforcement, } \\
\text { property rights, the police, the courts, as well as the likelihood } \\
\text { of crime and violence". }\end{array}$ & World Bank (WDI) \\
\hline $\begin{array}{l}\text { Corruption- } \\
\text { Control }\end{array}$ & $\mathrm{CC}$ & $\begin{array}{l}\text { "Control of corruption (estimate): captures perceptions of the } \\
\text { extent to which public power is exercised for private gain, } \\
\text { including both petty and grand forms of corruption, as well as } \\
\text { 'capture' of the state by elites and private interests". }\end{array}$ & World Bank (WDI) \\
\hline $\begin{array}{l}\text { Institutional } \\
\text { Governance }\end{array}$ & Instgov & $\begin{array}{l}\text { First Principal Component of Rule of Law and Corruption- } \\
\text { Control. The respect for citizens and the state of institutions } \\
\text { that govern the interactions among them }\end{array}$ & PCA \\
\hline $\begin{array}{l}\text { General } \\
\text { Governance }\end{array}$ & G.gov & $\begin{array}{l}\text { First Principal Component of Political, Economic and } \\
\text { Institutional Governances }\end{array}$ & PCA \\
\hline Mobile phones & Mobile & Mobile phone subscriptions (per 100 people) & World Bank (WDI) \\
\hline Internet & Internet & Internet penetration (per 100 people) & World Bank (WDI) \\
\hline Trade Openness & Trade & Imports plus Exports of Commodities (\% of GDP) & World Bank (WDI) \\
\hline $\begin{array}{l}\text { Foreign } \\
\text { investment }\end{array}$ & FDI & Foreign Direct Investment inflows ( $\%$ of GDP) & World Bank (WDI) \\
\hline
\end{tabular}




\begin{tabular}{|c|c|c|c|}
\hline GDP growth & GDPg & Gross Domestic Product (GDP) growth (annual \%) & World Bank (WDI) \\
\hline Population growth & Popg & Population growth rate (annual \%) & World Bank (WDI) \\
\hline $\begin{array}{l}\text { Educational } \\
\text { Quality }\end{array}$ & Educ & Pupil teacher ratio in Primary Education & World Bank (WDI) \\
\hline Foreign aid & Aid & Total Development Assistance (\% of GDP) & World Bank (WDI) \\
\hline
\end{tabular}

WDI: World Bank Development Indicators. PCA: Principal Component Analysis.

Appendix 2: Summary statistics (2000-2012)

\begin{tabular}{llllll}
\hline & Mean & SD & Minimum & Maximum & Observations \\
\cline { 2 - 5 } Political Stability & -0.543 & 0.956 & -3.323 & 1.192 & 578 \\
Voice \& Accountability & -0.646 & 0.737 & -2.233 & 0.990 & 578 \\
Political Governance & 0.000 & 1.292 & -3.440 & 2.583 & 578 \\
Government Effectiveness & -0.771 & 0.620 & -2.450 & 0.934 & 577 \\
Regulation Quality & -0.715 & 0.644 & -2.665 & 0.983 & 578 \\
Economic Governance & 0.002 & 1.367 & -4.049 & 3.807 & 577 \\
Rule of Law & 0.002 & 1.367 & -4.049 & 3.807 & 577 \\
Control of Corruption & -0.642 & 0.591 & -1.924 & 1.249 & 579 \\
Institutional Governance & 0.0002 & 1.364 & -3.588 & 3.766 & 578 \\
General Governance & 0.004 & 2.210 & -6.308 & 5.561 & 577 \\
Mobile phone penetration & 23.379 & 28.004 & 0.000 & 147.202 & 572 \\
Internet Penetration & 4.152 & 6.450 & 0.005 & 43.605 & 566 \\
Trade Openness & 78.177 & 36.138 & 20.964 & 209.87 & 597 \\
Foreign Direct Investment inflows & 5.332 & 8.737 & -6.043 & 91.007 & 603 \\
GDP growth & 4.714 & 6.322 & -47.552 & 63.379 & 608 \\
Population growth & 2.361 & 0.948 & -1.081 & 6.576 & 588 \\
Educational Quality & 43.601 & 14.529 & 12.466 & 100.236 & 481.187 \\
Foreign aid & 11.687 & 14.193 & -0.253 & & 606 \\
\hline S.D: Stan & & & & & \\
\hline
\end{tabular}

S.D: Standard Deviation. 
Appendix 3: Correlation analysis (uniform sample size: 319)

\begin{tabular}{|c|c|c|c|c|c|c|c|c|c|c|c|c|c|c|c|c|c|c|}
\hline \multicolumn{3}{|c|}{ Political Governance } & \multicolumn{3}{|c|}{ Economic Governance } & \multicolumn{3}{|c|}{ Institutional Governance } & \multirow{2}{*}{ G.gov } & \multicolumn{2}{|c|}{ ICT } & \multicolumn{2}{|c|}{ Openness } & \multicolumn{4}{|c|}{ Control Variables } & \\
\hline PS & VA & Polgov & GE & $\mathrm{RQ}$ & Ecogov & $\mathrm{CC}$ & RL & Instgov & & Internet & Mobile & Trade & FDI & GDPg & Popg & Educ & Aid & \\
\hline \multirow{18}{*}{1.000} & 0.678 & 0.909 & 0.649 & 0.574 & 0.634 & 0.661 & 0.802 & 0.765 & 0.811 & 0.377 & 0.338 & 0.283 & 0.009 & -0.070 & -0.314 & -0.366 & -0.114 & PS \\
\hline & 1.000 & 0.922 & 0.793 & 0.758 & 0.803 & 0.655 & 0.822 & 0.771 & 0.882 & 0.417 & 0.366 & 0.082 & -0.046 & 0.056 & -0.314 & -0.350 & -0.078 & VA \\
\hline & & 1.000 & 0.790 & 0.731 & 0.788 & 0.718 & 0.887 & 0.838 & 0.925 & 0.434 & 0.385 & 0.196 & -0.021 & -0.004 & -0.342 & -0.390 & -0.104 & Polgov \\
\hline & & & 1.000 & 0.868 & 0.969 & 0.808 & 0.888 & 0.887 & 0.940 & 0.449 & 0.441 & 0.101 & -0.054 & 0.025 & -0.410 & -0.292 & -0.205 & GE \\
\hline & & & & 1.000 & 0.963 & 0.682 & 0.790 & 0.770 & 0.874 & 0.288 & 0.394 & 0.072 & -0.078 & -0.007 & -0.349 & -0.294 & -0.235 & RQ \\
\hline & & & & & 1.000 & 0.774 & 0.870 & 0.860 & 0.940 & 0.384 & 0.433 & 0.090 & -0.068 & 0.010 & -0.394 & -0.357 & -0.227 & Ecogov \\
\hline & & & & & & 1.000 & 0.825 & 0.956 & 0.869 & 0.421 & 0.399 & 0.060 & -0.062 & -0.082 & -0.359 & -0.421 & -0.118 & $\mathrm{CC}$ \\
\hline & & & & & & & 1.000 & 0.954 & 0.961 & 0.462 & 0.403 & 0.201 & -0.039 & -0.030 & -0.371 & -0.406 & -0.145 & RL \\
\hline & & & & & & & & 1.000 & 0.957 & 0.462 & 0.420 & 0.135 & -0.053 & -0.059 & -0.381 & -0.433 & -0.138 & Instgov \\
\hline & & & & & & & & & 1.000 & 0.454 & 0.439 & 0.147 & -0.051 & -0.018 & -0.398 & -0.418 & -0.167 & G.gov \\
\hline & & & & & & & & & & 1.000 & 0.697 & 0.218 & 0.060 & -0.042 & -0.455 & -0.497 & -0.183 & Internet \\
\hline & & & & & & & & & & & 1.000 & 0.282 & 0.099 & -0.099 & -0.404 & -0.449 & -0.248 & Mobile \\
\hline & & & & & & & & & & & & 1.000 & 0.329 & -0.020 & -0.440 & -0.356 & -0.086 & Trade \\
\hline & & & & & & & & & & & & & 1.000 & 0.197 & 0.065 & -0.049 & 0.209 & FDI \\
\hline & & & & & & & & & & & & & & 1.000 & 0.181 & 0.139 & 0.124 & GDPg \\
\hline & & & & & & & & & & & & & & & 1.000 & 0.403 & 0.419 & Popg \\
\hline & & & & & & & & & & & & & & & & 1.000 & 0.196 & Edu \\
\hline & & & & & & & & & & & & & & & & & 1.000 & Aid \\
\hline
\end{tabular}

PS: Political Stability/Non violence. VA: Voice \& Accountability. Polgov: Political Governance. GE: Government Effectiveness. RQ: Regulation Quality. Ecogov: Economic Governance. CC: Corruption-Control. RL: Rule of Law. Instgov: Institutional Governance. G.Gov: General Governance. Internet: Internet Penetration. Mobile: Mobile Phone penetration. FDI: Foreign Direct Investment inflows. GDPg: GDP growth. Popg: Population growth. Edu : Educational quality. Aid: Foreign aid. 
Appendix 4: Persistence of the dependent variables

\begin{tabular}{|c|c|c|c|c|c|c|c|c|c|c|}
\hline & \multicolumn{3}{|c|}{ Political Governance } & \multicolumn{3}{|c|}{ Economic Governance } & \multicolumn{3}{|c|}{ Institutional Governance } & \multirow[b]{2}{*}{ G.gov } \\
\hline & PS & VA & Polgov & GE & RQ & Ecogov & $\mathrm{CC}$ & $\mathrm{RL}$ & Instgov & \\
\hline PS(-1) & 0.965 & & & & & & & & & \\
\hline $\mathrm{VA}(-1)$ & & 0.982 & & & & & & & & \\
\hline Polgov(-1) & & & 0.981 & & & & & & & \\
\hline $\mathrm{GE}(-1)$ & & & & 0.979 & & & & & & \\
\hline $\mathrm{RQ}(-1)$ & & & & & 0.981 & & & & & \\
\hline Ecogov(-1) & & & & & & 0.986 & & & & \\
\hline $\mathrm{CC}(-1)$ & & & & & & & 0.967 & & & \\
\hline RL(-1) & & & & & & & & 0.985 & & \\
\hline $\operatorname{Instgov}(-1)$ & & & & & & & & & 0.984 & \\
\hline G.gov(-1) & & & & & & & & & & 0.990 \\
\hline
\end{tabular}

PS: Political Stability/Non violence. VA: Voice \& Accountability. Polgov: Political Governance. GE: Government Effectiveness. RQ: Regulation Quality. Ecogov: Economic Governance. CC: Corruption-Control. RL: Rule of Law. Instgov: Institutional Governance. G.Gov: General Governance.

\section{References}

Amavilah, A., Asongu, S. A., \& Andrés, A. R., (2014). "Globalization, Peace \& Stability, Governance, and Knowledge Economy", African Governance and Development Institute Working Paper No. 14/012, Yaoundé.

Andrés, R. A, Asongu, S. A., Amavilah, V. H., (2015). "The Impact of Formal Institutions on Knowledge Economy”, Journal of the Knowledge Economy, 6(4), pp. 682-703.

Anyanwu, J. C., (2012). "Developing Knowledge for the Economic Advancement of Africa", International Journal of Academic Research in Economics and Management Sciences, 1(2), pp. 73-111.

Anyanwu, J., \& Erhijakpor, A., (2014). "Does Oil Wealth Affect Democracy in Africa?"African Development Review, 26 (1), pp. 15-37.

Arellano, M., \& Bond, S., (1991), "Some tests of specification for panel data: Monte Carlo evidence and an application to employment equations" The Review of Economic Studies, 58(2), pp. 277-297.

Arellano, M., \& Bover, O., (1995), “Another look at the instrumental variable estimation of error components models", Journal of Econometrics, 68(1), pp. 29-52.

Asiedu, E., (2014). "Does Foreign Aid in Education Promote Economic Growth? Evidence From Sub-Saharan Africa”, Journal of African Development, 16(1), pp. 37-59.

Asongu, S. A., (2013). "How has mobile phone penetration stimulated financial development in Africa", Journal of African Business, 14(1), pp. 7-18. 
Asongu, S. A., (2014a). "Globalization, (fighting) corruption and development: how are these phenomena linearly and nonlinearly related in wealth effect?, Journal of Economic Studies, 41(3), pp. 346-369.

Asongu, S. A., (2014b). “African development: beyond income convergence”, South African Journal of Economics, 83(3), pp. 334-353.

Asongu, S. A., (2017a). "Conditional Determinants of Mobile Phones Penetration and Mobile Banking in Sub-Saharan Africa", Journal of the Knowledge Economy.

DOI: $10.1007 \% 2 F s 13132-015-0322-\mathrm{z}$

Asongu, S. A., (2017b). "Knowledge Economy Gaps, Policy Syndromes and Catch-Up Strategies: Fresh South Korean Lessons to Africa", Journal of the Knowledge Economy, 8(1), pp. 211-253.

Asongu, S. A., (2015). "The impact of mobile phone penetration on African inequality", International Journal of Social Economics, 42(8), pp. 706-716.

Asongu, S. A., (2016). "Determinants of Growth in Fast Developing Countries: Evidence from Bundling and Unbundling Institutions”, Politics \& Policy, 44(1), pp. 97-134.

Asongu, S. A., Batuo, E., \& Tchamyou, S. V., (2016). "Bundling Governance: Finance versus Institutions in Private Investment Promotion", African Governance and Development Institute Working Paper No. 15/051, Yaoundé.

Asongu, S. A., \& De Moor, L., (2015). "Recent advances in finance for inclusive development: a survey", African Governance and Development Institute Working Paper No. 15/005, Yaoundé.

Asongu, S. A., \& De Moor, L., (2017). "Financial globalisation dynamic thresholds for financial development: evidence from Africa", The European Journal of Development 29(1), pp. 192-212.

Asongu, S. A., \& Nwachukwu, J., (2016a). "Revolution empirics: predicting the Arab Spring” Empirical Economics, 51(2), pp. 439-482.

Asongu, S. A., \& Nwachukwu, J., (2016b). "Foreign aid and governance in Africa", International Review of Applied Economics, 30(1), pp. 69-88.

Asongu, S. A., \& Nwachukwu, J., (2016c). "The Role of Lifelong Learning in Political Stability and Non-Violence: Evidence from Africa", Journal of Economic Studies, 43(1), pp. 141-164.

Asongu, S. A., \& Ssozi, J., (2016). "Sino-African Relations: Some Solutions and Strategies to the Policy Syndromes", Journal of African Business, 17(1), pp. 33-51.

Ba, J., \& Ng S (2006). "Confidence intervals for diffusion index forecasts and inference for factor-augmented regression”, Econometrica, 74(4), pp. 1133-1150. 
Bai, J., (2003). "Inferential theory for factor models of large dimensions". Econometrica, 71 (1),pp.135-173.

Bai, J., (2009). "Panel data models with interactive fixed effects". Econometrica, 77(4), pp. 1229-1279.

Baltagi, B. H., (2008). "Forecasting with panel data", Journal of Forecasting, 27(2), pp. 153173.

Barro, R., (1991). "Economic Growth in a Cross Section of Countries". Quarterly Journal of Economics 196 (2/May), pp. 407-443.

Barro, R. J., \& Sala-i-Martin, X., (1992). "Convergence”, Journal of Political Economy, 100(2), pp. 223-251.

Barro, R. J., \& Sala-i-Martin, X., (1995). Economic Growth. The MIT Press, Cambridge, MA.

Baumol, W. J., (1986). "Productivity, growth, convergence and welfare: what the long run data show", American Economic Review, 76(5), pp. 1072-1085.

Bonaglia, F., Braga de Macedo, J., \& Bussolo M., (2001). "How globalization improves governance". Working Paper No. 181. OECD Development Center. November.

Bond, S., Hoeffler, A., \& Tample, J. (2001) “GMM Estimation of Empirical Growth Models”, University of Oxford.

Boulianne, S., (2009). "Does Internet Use Affect Engagement? A Meta-Analysis of Research", Political Communication, 26(2), pp. 193-211.

Blundell, R., \& Bond, S., (1998). "Initial conditions and moment restrictions in dynamic panel data models" Journal of Econometrics, 87(1), pp. 115-143.

Brambor, T., Clark, W. M., \& Golder, M., (2006). "Understanding Interaction Models:Improving Empirical Analyses”, Political Analysis, 14 (1), pp. 63-82.

Breuer, A., Landmann, T., \& Farquhar, D., (2012). "Social media and protest mobilization: evidence from the Tunisian revolution", Democratization, 22(4), pp. 764-792.

Bruno, G., De Bonis, R., \& Silvestrini, A., (2012). "Do financial systems converge? New evidence from financial assets in OECD countries". Journal of Comparative Economics; 40(1), pp. 141-155.

Carmody, P., (2013). "A knowledge economy or an information society in Africa? Thintegration and the mobile phone revolution", Information Technology for Development, 19(1), pp. 24-39.

Byrne, E., Nicholson, B., \& Salem, F., (2011). "Information communication technologies and the millennium development goals", Information Technology for Development, 17(1), pp. 1-3. 
Chavula, H. K., (2013). "Telecommunications development and economic growth in Africa", Information Technology for Development, 19(1), pp. 5-23.

Cheung, H. Y., \& Chan. A. W. H., (2008). "Corruption Across Countries; Impacts form Education and Cultural Dimensions.”, The Social Science Journal, 45 (2), pp. 223-239.

Claus, I., \& Grimes, A., (2003). “Asymmetric Information, Financial Intermediation and the Monetary Transmission Mechanism: A Critical Review”, NZ Treasury Working Paper No. 13/019, Wellington.

Dewan, S., \& Ramaprasad, J., (2014). "Social media, traditional media and music sales", MIS Quarterly, 38(1), pp. 101-128.

Diamond, L., (2010). “Liberation Technology”, Journal of Democracy, 21(3), pp. 69-83.

Dixit, A., (2009). "Governance Institutions and Economic Activity", American Economic Review, 99(1), pp. 5-24.

Efobi, U., (2015). "Politicians' Attributes and Institutional Quality in Africa: A Focus on Corruption", Journal of Economic Issues, 49(3), pp. 787-813.

Fonchingong, C., (2014). "Firming Up Institutional Policy for Deprived Elderly in Cameroon”, Politics \& Policy, 42(6), pp. 948-980.

Fosu, A., (2013a), "Growth of African Economies: Productivity, Policy Syndromes and the Importance of Institutions" Journal of African Economies, 22(4), pp. 523-551.

Fosu, A., (2013b). "Growth of African Economies: Productivity, Policy Syndromes and the Importance of Institutions” Journal of African Economies 22(4), pp. 523-551.

Fosu, A. K., (2015a). "Growth, Inequality and Poverty in Sub-Saharan Africa: Recent Progress in a Global Context", Oxford Development Studies, 43(1), pp. 44-59.

Fosu, A., (2015b). Growth and Institutions in African Development, First edited by Augustin K. Fosu, , Routledge Studies in Development Economics: New York

Fosu, A., (2015c). Growth and institutions in African Development, in Growth and Institutions in African Development, First edited by Augustin K. Fosu, 2015, Chapter 1, pp. 1-17, Routledge Studies in Development Economics: New York.

Fukuyama, F., (2013). “What is Governance?”, Governance, 26(3), pp. 347-368.

Fung, M. K., (2009). "Financial development and economic growth: convergence or divergence?”. Journal of International Money and Finance, 28(1), pp.56-67.

Gagliardone, I., (2015). “'Can you hear me?' Mobile-radio interactions and governance in Africa”, new media and society, doi: 10.1177/1461444815581148. 
Gani, A., (2011). "Governance and Growth in Developing Countries", Journal of Economic Issues, 45(1), pp. 19-40.

Goredema, C, (2009). "Recovery of proceeds of crime: observations on practical challenges in Sub-Saharan Africa.” In Basel Institute on Governance, Tracing Stolen Assets: A

Practitioner's Handbook. Available at: http://www.

baselgovernance.org/fileadmin/docs/publications/books/asset-tracing_web-version.pdf (0626-14)

Greenaway-McGrevy, R., Han, C., \& Sul, D., (2012). "Asymptotic distribution of factor augmented estimators for panel regression”. Journal of Econometrics, 169 (1), pp. 48-53.

Grossman, G., Humphreys, M., and Sacramone-Lutz, G., (2014). ““'I wld like u WMP to extend electricity 2 our village": On Information Technology and Interest Articulation", American Political Science Review, 108(3), pp. 688-705.

Hellstrom, J. (2008 ), "Mobile phones for good governance- challenges and way forward", Stockholm University / UPGRAID,

http://www.w3.org/2008/10/MW4D_WS/papers/hellstrom_gov.pdf (Accessed: 22/11/2015).

Jolliffe, I. T. (2002) Principal Component Analysis (2nd Ed.) New York: Springer.

Kaffenberger, M., (2012). "The effect of educational attainment on corruption participation in sub-Saharan Africa”, Graduate School of Vanderbilt University.

Kaiser, H. F. (1974) “An index of factorial simplicity” Psychometrika, 39(1), pp. 31-36.

Kamel, S., (2005). "The use of information technology to transform the banking sector in developing nations", Information Technology for Development, 11(4), pp. 305-312.

Kaufmann, D., Kraay, A., \& Mastruzzi, M., (2007a). "Growth and Governance: A Reply”, Journal of Politics, 69(2), pp. 555-562.

Kaufmann, D., Kraay, A., \& Mastruzzi, M., (2007b). "Growth and Governance: A Rejoinder", Journal of Politics, 69(2), pp. 570-572.

Kaufmann, D., Kraay, A \& Mastruzzi, M., (2010). "The worldwide governance indicators: Methodology and analytical Issues". World Bank Policy Research Working Paper No 5430, Washington.

Kivuneki, F. N., Ekenberg, L., Danielson, M., \& Tusubira. F.F., (2011). "Perceptions of the role of ICT on quality of life in rural communities in Uganda", Information Technology for Development, 21(1), pp. 61-80.

Klitgaard, R., (1988). Controlling Corruption, University of California Press, Berkeley and London. 
Kuada, J., (2015). Private Enterprise-Led Economic Development in Sub-Saharan Africa The Human Side of Growth First edition by Kuada, J, Palgrave Macmillan: New York.

Kurtz, M., \& Schrank, A., (2007a). "Growth and Governance: Models, Measures, and Mechanisms”, Journal of Politics, 69(2), pp. 538-554.

Kurtz, M., \& Schrank, A., (2007b). "Growth and Governance: A Defense", Journal of Politics, 69(2), pp. 563-569.

Lalountas, D. A., Manolas, G.A., \& Vavouras, I.S., (2011), “Corruption, globalization and development: How are these three phenomena related?", Journal of Policy Modeling, 33, pp.636-648.

Lederman, D., Loayza, N. V., \& Soares, R. R., (2005). “Accountability and Corruption: Political Institutions Matter”, Economics \& Politics, 7(1), pp. 1-35.

Levendis, J., \& Lee, S. H., (2013). "On the endogeneity of telecommunications and economic growth: evidence from Asia", Information Technology for Development, 19(1), pp. $62-85$.

Love, I., \& Zicchino, L., (2006). "Financial Development and Dynamic Investment Behaviour: Evidence from Panel VAR" .The Quarterly Review of Economics and Finance, 46(2), pp. 190-210.

Manacorda, M., \& Tesei, A., (2016). "Liberation Technology: Mobile Phones and Political Mobilization in Africa", Queen Mary University of London, http://personal.1se.ac.uk/manacorm/liberation_technology.pdf (Accessed: 24/05/2016).

Mankiw, N. G., Romer, D., \& Weil, D. N., (1992). "A contribution to the empirics of economic growth”, Quarterly Journal of Economics, 107(May), pp. 407-437.

Matthias, M., (2012). "Connectivity and Accountability in Africa", The Futurist, 46(1), pp. 67.

Mayer-Foulkes, D., (2010). "Divergences and Convergences in Human Development". UNDP Human Development Research Paper 2010/20, Paris.

McKenzie C, R., \& McAleer M (1997). "On efficient estimation and correct inference in models with generated regressors: A general approach.” Japanese Economic Review, 48(4), pp. 368-389.

McMillan, M,S., (2013). “The Changing Structure of Africa's Economies.” Background Paper for African Economic Outlook 2013. African Development Bank, OECD Development Center, and United Nations Development Program. Revised version available at: http://legacy.wlu.ca/documents/57803/McMillian_ChangingAfrica_140317.pdf (Accessed: 24/05/2016). 
Michel, J., (2016). "Beyond Aid: the Integration of Sustainable Development in a Coherent International Agenda", Centre for International Private Enterprises, http://www.cipe.org/publications/detail/beyond-aid-integration-sustainable-developmentcoherent-international-agenda (Accessed: 19/07/2016).

Mocan, N., (2008). "What Determines Corruption? International Evidence from Microdata." Economic Inquiry, 46 (4), pp. 493-510.

Mpogole, H., Usanga, H., \& Tedre, M., (2008). "Mobile phones and poverty alleviation: a survey study in rural Tanzania", Proceedings of M4D 2008, Karlstad University, Sweden, pp. $62-72$.

Narayan, P. K., Mishra, S., \& Narayan, S., (2011). "Do market capitalization and stocks traded converge? New global evidence", Journal of Banking and Finance, 35(10), pp. 27712781.

Okada, K., \& Samreth, S.,(2012), “The effect of foreign aid on corruption: A quantile regression approach”, Economic Letters, 115(2), pp. 240-243.

Oluwatobi, S., Efobi, U.R., Olurinola, O.I., Alege, P. (2015), "Innovation in Africa: Why Institutions Matter”, South African Journal of Economics, 83(3), pp. 390-410.

Oxley L, \& McAleer, M., (1993). "Econometric issues in macroeconomic models with generated regressors.” Journal of Economic Surveys, 7(1), pp. 1-40.

Pagan, A., (1984). "Econometric issues in the analysis of regressions with generated regressors" International Economic Review, 25(1), pp. 221-247.

Penard, T., Poussing, N., Yebe, G. Z., \& Ella, P. N., (2012). "Comparing the Determinants of Internet and Cell Phone Use in Africa: Evidence from Gabon ", Communications \& Strategies, 86 (Second Quarter), pp. 65-83.

Pesaran, M. H., (2006). "Estimation and inference in large heterogeneous panels with a multifactor error structure”. Econometrica 74 (4), pp. 967-1012.

Petrakis, P. E., \& Stamatakis, D. (2002). “Growth and educational levels: a comparative analysis”. Economics of Education Review, 21 (2), pp. 513-521.

Pierskalla, J. H., \& Hollenbach, F. M., (2013). "Technology and Collective Action: The Effect of Cell Phone Coverage on Political Violence in Africa", American Political Science Review, 107(2), pp. 207-224.

Ponelis, S. R., \& Holmner, M. A., ( 2013a). "ICT in Africa: Enabling a Better Life for All”, Information Technology for Development, 21(1), pp. 1-11.

Ponelis, S. R., \& Holmner, M. A., ( 2013b). "ICT in Africa: Enabling a Better Life for All”, Information Technology for Development, 21(1), pp. 163-177. 
Porter, G., Hampshire, K., Milner, J., Munthali, A., Robson, E., De Lannoy, A., Bango, A., Gunguluza, N., Mashiri, M., Tanle, A., and Abane, A., (2016). "Mobile Phones and Education in Sub-Saharan Africa: From Youth Practice to Public Policy", Journal of International Development, 28(1), pp. 22-39.

Qureshi, S., (2013a). "What is the role of mobile phones in bringing about growth?", Information Technology for Development, 19(1), pp. 1-4.

Qureshi, S., (2013b). "Networks of change, shifting power from institutions to people: how are innovations in the use of information and communication technology transforming development?" ?", Information Technology for Development, 19(2), pp. 97-99.

Qureshi, S., (2013c). "Information and Communication Technologies in the Midst of Global Change: How do we Know When Development Takes Place?", Information Technology for Development, 19(3), pp. 189-192.

Roodman, D., (2009a). "A Note on the Theme of Too Many Instruments", Oxford Bulletin of Economics and Statistics, 71(1), pp. 135-158.

Roodman, D., (2009b). "How to do xtabond2: An introduction to difference and system GMM in Stata”, Stata Journal, 9(1), pp. 86-136.

Sayari, S., (1977). "Political Patronage in Turkey", in E. Gellner and J. Waterbury (eds.), Patonsand Clients in Mediterranean Societies, London: Duckworth, pp. 103-113.

Scott, J. C., (1972). Comparative Political Corruption, Englewood Cliffs, NJ: Prentice-Hall.

Snow, B. C., (2009). "Mobile Phone Diffusion and Corruption in Africa", Political Communication, 26(3), pp.333-353.

Solow, R. M., (1956). "A contribution to the theory of economic growth", Quarterly Journal of Economics, 70(1), pp. 65-94.

Stock, J. H. \& M. W. Watson (2002). "Forecasting using principal components from a large number of predictors". Journal of the American Statistical Association, 97 (460), pp.11671179.

Suarez, S. L., (2006). "Mobile democracy: text messages, voter turnout and the 2004 Spanish general election”, Representation, 42(2), pp. 117-128.

Swan, T., (1956). "Economic growth and capital accumulation”. Economic Record, 32, pp. 334-361.

http://onlinelibrary.wiley.com/doi/10.1111/saje.12100/abstract

Tchamyou, V. S., (2015). "The role of knowledge economy in African business", African Governance and Development Institute Working Paper, No. 15/049, Yaoundé. 
Tchamyou, V. S., \& Asongu, S. A., (2017). "Information Sharing and Financial Sector Development in Africa”, Journal of African Business, 18(1), pp. 24-49.

Treisman, D., (2000).“ The causes of corruption: a cross-national study”, Journal of Public Economics, 76(3), pp. 399-457.

Truex, R., (2011). “Corruption, Attitudes, and Education: Survey Evidence from Nepal." World Development, 39 (7), pp. 1133-42.

Tusalem, R. F., (2015), "State Regulation of Religion and the Quality of Governance", Politics \& Policy, 43(1), pp. 94-141.

Varese, F., (1997). "The Transition to the Market and Corruption in Post-socialist Russia", Political Studies, 45(3), pp. 579-96.

Weidmann, J. N., \& Shapiro, N. B., (2015). "Is the Phone Mightier Than the Sword?

Cellphones and Insurgent Violence in Iraq", International Organisation, 69(2), pp. 247-274.

Westerlund, J., \& Urbain, J-P., (2013a). "On the estimation and inference in factor-augmented panel regressions with correlated loadings", Economic Letters, 119(3), pp. 247-250.

Westerlund, J., \& Urbain, J-P., (2013b). "On the implementation and use of factor-augmented regressions in panel data”, Journal of Asian Economics, 28(October), pp. 3-11.

Westerlund, J., \& Urbain, J-P., (2012). “Cross-sectional averages versus principal components", Maastricht University, RM/11/053, Maastricht.

Weyland, K., (1998). “The Politics of Corruption in Latin America”. Journal of Democracy, 9 (2), pp.108-121.

Wade, R., (1985). "The Market for Public Office: Why the Indian State is not better at Development.", World Development, 13(4), pp. 467-97.

World Bank (2015). "World Development Indicators", World Bank Publications http://www.gopa.de/fr/news/world-bank-release-world-development-indicators-2015

(Accessed: 25/04/2015).

Yerrabati, S., \& Hawkes, D., (2015). "Economic Governance and Economic Growth in South and East Asia \& Pacific Region: Evidence from Systematic Literature Reviews and Metaanalysis". Advances in Economics and Business, 3(1), pp. 1 - 21. 